\title{
Immigration Enforcement and Economic Resources of Children With Likely Unauthorized Parents ${ }^{1}$
}

\author{
Catalina Amuedo-Dorantes ${ }^{2}$ \\ Esther Arenas-Arroyo ${ }^{3}$ \\ Almudena Sevilla ${ }^{4}$
}

August 3, 2017

\begin{abstract}
Over the past two decades immigration enforcement has grown exponentially in the United States. Using data from the 2005 through 2011 American Community Survey, we exploit the geographical and temporal variation in a novel index of the intensity of immigration enforcement to show how the average yearly increase in interior immigration enforcement over that period raised the likelihood of living in poverty of households with U.S. born children by 4 percent. The effect is robust to a number of identification tests accounting for the potential endogeneity of enforcement policies and residential location of immigrants, and is primarily driven by police-based immigration enforcement measures adopted at the local level, such as $287(\mathrm{~g})$ agreements.
\end{abstract}

JEL Codes: I38, J15, K37

Keywords: Immigration Enforcement, Poverty, U.S. Born Children, Unauthorized Parents

\footnotetext{
${ }^{1}$ The authors are grateful to Mary Lopez, Tara Watson as well as to participants at the Meeting of the European Economic Association 2015 in Mannheim, the 2016 Annual Conference of the Royal Economic Society, the SOLE Conference 2016, the 2016 Barcelona Summer School and the Second Workshop on the Economics of Migration in Frankfurt for their comments to earlier drafts.

${ }^{2}$ San Diego State University, 5500 Campanile Drive, San Diego, CA 92182, USA, email:

camuedod@mail.sdsu.edu

${ }^{3}$ Corresponding author. Centre on Migration, Policy and Society (COMPAS), University of Oxford, 58 Banbury Road, Oxford, OX2 6QS, Oxfordshire, UK. Email:esther.arenas-arroyo@compas.ox.ac.uk ${ }^{4}$ Queen Mary University of London, Francis Bancroft Building, Room 4.13D, Mile End Road, London, E1 4NS, Telephone: +44 (0) 207882 5617, email: a.sevilla@qmul.ac.uk.
} 
"Are we a nation that kicks out a striving, hopeful immigrant $\{\ldots\}$ or are we a nation that finds a way to welcome her in?"

President Barack Obama, November 2014

\section{Introduction}

This paper explores how the intensification of immigration enforcement at the local and state levels that has been taking place in the United States since 9/11 is impacting the economic resources and poverty exposure of American children with unauthorized parents. To this date, the analyses have been primarily focused on the impact of specific measures, mostly employment verification mandates, on the employment and, sometimes, earnings of working-age individuals. In this paper, we address the aforementioned gap with an analysis of the role of intensified interior immigration enforcement on the economic resources and the likelihood of life in poverty of households of U.S. born children with a likely unauthorized parent.

We focus on mixed-status households with U.S. born children, ${ }^{5}$ as opposed to working-age adults, for various reasons. First, in 2012, there were 4.5 million of U.S. born children living with at least one unauthorized parent, doubled the number in 2002; furthermore, this demographic accounted for 8 percent of all American children (see Passel et al. 2014). Second, these mixed-status households, which may include households with some older unauthorized siblings who immigrated with their parents, are particularly vulnerable to poverty. They represent 11 per cent of the people living in poverty -about twice their population share. Finally, by now, it is well known that economic resources play a decisive role on children's health, education, and development outcomes later in life. ${ }^{6}$ As such, understanding how the piecemeal approach to immigration enforcement is impacting the

\footnotetext{
${ }^{5}$ We use the term mixed-status to refer to households where some individuals are U.S. citizens (as would be the case with the U.S. born children by virtue of birth right citizenship, whereas others (at least one of the parents, although it could also include siblings) are likely unauthorized.

${ }^{6}$ See for example, Case et al. 2002, Almond and Currie 2011, Bailey and Dynarski 2011 and Levine and Zimmerman 2010, among others.
} 
exposure to poverty of many U.S. born or American children is crucial for a well-informed debate of comprehensive immigration reform and for the design of policies that safeguard children's well-being.

We use household-level data from the 2005 through 2011 American Community Survey (ACS), to which we merge self-collected information on the intensity of immigration enforcement at the local and state levels from a wide range of immigration enforcement measures (E-Verify mandates, 287(g) agreements, omnibus immigration laws and the Securities Communities program). Crucially, we exploit the geographical and temporal variation in the intensity of immigration enforcement to identify the impact of tougher immigration enforcement on economic resources, net of other macro-economic factors that may have contributed to the generalized poverty increase during the 2000-2009 decade (Peri 2013).

We find that a one standard deviation increase in the intensity of interior immigration enforcement (roughly twice the average increase in this type of enforcement during the time period under examination) raises the likelihood of life in poverty of households of U.S. born children with at least one likely unauthorized parent by 4 percent. Additionally, it lowers their household incomes by 19 percent and their propensity to participate in the Food Stamps program by 7 percent. This finding is robust to alternative measures of our dependent variable, to the definition of who is considered a likely unauthorized migrant, and to the exclusion of specific downturn years or of counties that are particularly harsher in their implementation of immigration enforcement measures, as in the case of Maricopa County in Arizona. In addition, our empirical results hold after taking into account the possible endogeneity of the immigration enforcement polices, and the self-selection of immigrants into particular locations. 
We also explore the channels through which intensified immigration enforcement might have exposed families to a greater likelihood of life in poverty. There are several channels through which intensified enforcement can increase the exposure to life in poverty of households headed by unauthorized parents. One channel commonly looked at in the literature is direct employment restrictions imposed, for example, by employment verification mandates (E-Verify). By screening new hires to assess their work eligibility, E-Verify mandates can potentially curtail the job opportunities of unauthorized immigrants, limit their working conditions and result in lower earnings -all of which can contribute to a higher likelihood of life in poverty.

Another two channels include fear of apprehension and the deportation of the main household earner. Fear of apprehension may steer families to live in the shadows in order to minimize detention and deportation risks. Such behavior can have labor market consequences, potentially leading those working to forego profitable employment opportunities, work less and increase their exposure to life in poverty. Similarly, the deportation of the main household earner can severely cut back a household's economic resources. Survey evidence suggests that these fears may be behind the reporting of difficulties in obtaining social or government services, in finding legal assistance, or in obtaining health care services by unauthorized immigrants while in the United States (see Amuedo-Dorantes et al. 2013).

To tease out whether the effect from tougher immigration enforcement comes from direct employment restrictions or from fear of apprehension and/or deportation, we assess the impact of different types of policies. In particular, we compare the effect of E-Verify mandates, which we refer to as employment-based enforcement measures as opposed to the effect from police-based enforcement measures unrelated to employment but that are directly linked to apprehension and deportation. We find that police-based enforcement measures, 
particularly those adopted at the local level, seem responsible for the increased poverty exposure of households of U.S. born children with a likely unauthorized parent. This finding, consistent with the idea that employment verification mandates might be hurting the employment opportunities of likely unauthorized immigrants in the household, is suggestive of police-based enforcement ultimately having a greater economic damage on the household. We explore whether this economic damage is even present in the absence of one of the parents' deportations and find that it is also observable among intact households -suggesting that deportation fears alone might be sufficient for the household to endure economic hardship.

Our study contributes to a growing body of work examining the impact of tougher immigration policies on unauthorized immigrants and their families by looking at household economic outcomes, compared to other outcomes analyzed in the literature such as residential choices, crime, labor market outcomes and Medicaid participation (e.g. Amuedo-Dorantes et al. 2013, Thomas J. and Adam B. (2014) Kostandini et al. 2013, Watson 2013, Bohn et al. 2014, Watson 2014). Second, to this date, the analyses on economic outcomes have been primarily focused on the impact of specific measures, mostly employment verification mandates, on the employment and, sometimes, earnings of working-age individuals (see, Amuedo-Dorantes and Bansak (2012), Bohn and Lofstrom (2013), Bohn et al. (2014), Kostandini et al. (2013) ). Compared to this strand of research, ours is the first paper addressing the impact of the typically simultaneous implementation of a diverse set of interior immigration enforcement measures. Looking at the impact of a broad set of simultaneously implemented measures enables us to identify the type of measures responsible for the found impacts, as well as to identify previously overlooked channels through which tougher enforcement ends up impoverishing these households. Third, previous studies cannot shed light onto what happens to household economic resources based on findings from 
individuals -after all, other household members may increase their labor force participation in order to make up for any loss in household income. By looking at the household, we are able to do so and assess if that is the case.

This paper is organized as follows. Section 2 contains a thorough description of the enforcement legislation over the timer period being examined. Section 3 discusses the enforcement and poverty data. Section 4 describes the methodology to identify the causal effect from increased employment. Section 5 presents the main findings, whereas section 6 investigates the policy channels and mechanisms through which increased enforcement may lead to increases in poverty. Section 7 concludes the study.

\section{Institutional Framework}

The Illegal Immigration Reform and Immigrant Responsibility Act of 1996 (IIRIRA) regulated some of what would become model measures of interior immigration enforcement over the past decade, such as the $287(\mathrm{~g})$ agreements. Broadly speaking, interior enforcement initiatives over the past decades can be grouped into what we refer to as police-based measures involving the local or state police (e.g. 287(g) agreements, Secure Communities and omnibus immigration laws), and employment-based measures, which involve employers (i.e. employment verification mandates; henceforth E-Verify). Typically, police-based measures involve agreements between the Director of the Immigration and Customs Enforcement agency (ICE) and state and local (country, town, and city level) law enforcement agencies. These agreements allow designated officers to perform immigration law enforcement functions, provided that they have appropriate training and function under the supervision of ICE officers. Examples of law enforcement agencies that signed these agreements include Etowah County Sheriff's Office, Arizona Department of Corrections,

City of Mesa Police Department, Pinal County Sherriff's Office. In contrast, E-verify mandates require employers to screen newly hired workers for work eligibility (see Appendix 
A for a detailed description of each of these measures). ${ }^{7}$ In what follows, we refer to both of these categories of immigration enforcement measures and to their relationship to poverty among households of U.S. born children with a likely unauthorized parent.

\subsection{Police-based Immigration Enforcement Measures}

Police-based immigration enforcement measures have evolved over time. We focus on three of them: 287(g) agreements, Secure Communities and omnibus immigration laws. Active since 2002, 287(g) agreements were one of the earliest police-based immigration enforcement measures. Unlike E-Verify, which is typically announced by a door sticker letting prospective employees know about the use of E-Verify in that company, migrants never know when the police might stop them and request proper identification. And, unlike E-Verify, police-based immigration enforcement measures are directly linked to deportations.

Police-enforcement measures provided local and state police officers the authority to interrogate any immigrant, arrest without warrant, and begin the removal process (under a "task force" agreement). They also allowed police officers to question immigrants who have been arrested about their immigration status (under a "jail enforcement" agreement). In 2006, only five counties partnered with the federal government. By 2008, that number had jumped to 41 counties (Wong 2012). Between 2006 and 2010, the budget for 287(g) increased from $\$ 5$ million to $\$ 68$ million, with over 1,500 state and local law enforcement officers trained and granted authorization to enforce federal immigration laws (Nguyen and Gill 2010).

In 2008, Secure Communities was introduced. The Secure Communities program (2008-2014), designed to replace the 287(g) agreements, prioritized immigration enforcement among non-citizens who had committed serious crimes. The fingerprints of detainees were checked against the databases from the Federal Bureau of Investigation (FBI) and from the

\footnotetext{
${ }^{7}$ Detailed information on the various policies can be found in Appendix A.
} 
Department of Homeland Security (DHS) in order to get information on past criminal arrests, convictions, and immigration history. By the end of 2013, all the nation's 3,181 jurisdictions were participating in Secure Communities (U.S. Immigration and Customs Enforcement (ICE) 2013). The Secure Communities program was replaced by the Priority Enforcement Program (PEP) in 2015, which continues to rely on fingerprint-based biometric data submitted by state and local law enforcement agencies and is mostly targeted to unauthorized immigrants convicted of specific crimes. ${ }^{8}$

In contrast to most $287(\mathrm{~g})$ agreements and participation in the Secure Community program, which are mostly implemented at the local level, omnibus immigration laws (2010present) are statewide police-based enforcement measures. Arizona was the first state to sign an omnibus immigration law in 2010. While the content of each omnibus immigration law differs, they often include a "show me your papers" clause", which enables the police to request proper identification documentation during a lawful stop. Nonetheless, in some instances, omnibus immigration laws have gone as far as to require that schools verify students' legal status. ${ }^{9}$ The first and only omnibus immigration law we are able to capture with our data is the "Support Our Law Enforcement and Safe Neighborhoods Act" (henceforth SB1070), which was signed by Arizona's governor on April 19, 2010. Deemed to be one of the tougher immigration laws on its day, SB1070 considers a crime not registering with the U.S. authorities if an immigrant has been living in the United States for more than 30 days, or if they do not have their documents with them at all times. It also requires state and local enforcement officers to check an individual's immigration status during a "lawful stop, detention or arrest" if there is suspicion that the person is an undocumented immigrant. By the end of April 2010, HB2162 was passed, amending SB1070

\footnotetext{
${ }^{8}$ See: http://www.dhs.gov/sites/default/files/publications/14_1120_memo_secure_communities.pdf

${ }^{9}$ See Alabama's HB56, National Conference of State Legislatures 2012, at: http://www.ncsl.org/research/immigration/omnibus-immigration-legislation.aspx\#Fifty-Three_Omnibus_Bills
} 
to avoid racial and ethnic profiling. One day before these laws were to become effective, the U.S. Department of Justice argued that SB1070 was unconstitutional and filed a lawsuit asking for an injunction against it. The law's most questionable provisions were blocked. ${ }^{10}$

${ }^{10}$ See: http://www.ncsl.org/research/immigration/analysis-of-arizonas-immigration-law.aspx 


\subsection{Employment-based Immigration Enforcement Measures}

Employment-based immigration enforcement is exemplified by employment verification mandates (E-Verify). E-verify is an electronic program that allows employers to screen newly hired workers for work eligibility. The program is administered by the U.S. Department of Homeland Security in partnership with the Social Security Administration. While the use of E-Verify is obligatory in the hiring of federal employees, it has been optional at other levels. Some states have mandated its use, either by public agencies and contractors working for public agencies or, in more extreme cases, by all employers in the state. The first E-Verify mandate was implemented in 2006 in the state of Colorado. With EVerify, the employer introduces the biographic information (name, social security number, date of birth, citizenship and alien registration number) of the prospective employee into an online program. The software program then cross-checks the prospective employee's records between those in the Social Security Administration (SSA) database and the records from the Department of Homeland Security (DHS) to determine whether the worker is authorized to work in United States. In the case that work eligibility is not confirmed, the employer receives a "tentative no confirmation" that the worker has to resolve within eight business days. By 2014, the number of employers enrolled in E-Verify had risen to 482,692. ${ }^{11}$

The E-verify program is far from perfect when detecting identity fraud, and it still renders a large number of false positives and negatives despite recent improvements. While false positives are often related to document fraud, false negatives occur when the system fails to confirm the eligibility to work in the United States of someone authorized to do so, either due to errors in the way the employer entered the information, or to outdated, missing and/or erroneous information in the federal database (see Meissner et al. 2013).

\footnotetext{
${ }^{11}$ See: http://www.uscis.gov/e-verify/about-program/history-and-milestones
} 


\section{Data}

Our main aim is to explore the impact that intensified interior immigration enforcement is having on the likelihood that households of American children with likely unauthorized parents live in poverty. To that end, we use household-level data from the U.S. Census Bureau's American Community Survey (ACS), along with self-collected local and state level data on the implementation of the following immigration enforcement measures: E-Verify mandates, 287(g) agreements, omnibus immigration laws and the Securities Communities program.

\subsection{The American Community Survey}

The ACS data is a yearly national survey conducted by the U.S Census Bureau produced by the Integrated Public Use Microdata Series (Ruggles et al. 2015). Every year approximately 3.5 million randomly sampled households take part, of which 24,000 are households of U.S. born children with an unauthorized parent. The ACS dataset is especially well-suited for the purpose of this paper for various reasons as it contains detailed information on the outcome of interest to this study -namely household poverty-, and a rich set of socio-demographic variables that can play a decisive role in understanding children's poverty exposure. We use the 2005 through 2011 ACS waves because the ACS consistently identifies the CONSPUMA where the household lives over that period. ${ }^{12}$

Our main dependent variable, a dummy for whether the household lives in poverty, takes the value of 1 if household income falls below the poverty line, and 0 otherwise $(e . g$. Bailey et al. 2014). This variable is created directly by ACS using detailed income and family structure information, as well as the poverty line established by the Social Security Administration. In 2010, the poverty line for a family of four (two adults plus two children)

\footnotetext{
${ }^{12}$ Because information on household income and poverty levels refer to the 12 months, we adjust our variables accordingly to refer to the same period.
} 
was $\$ 22,113$. There are a couple of important drawbacks to the official poverty measure (Bitler et al. 2014). The first one is the fact that the line does not vary geographically, even though it is inflation adjusted using the Consumer Price Index (CPI). The second drawback is that the line only refers to money income before taxes. It does not include capital gains or noncash benefits, such as public housing, Medicaid, and food stamps. This is, however, less likely to prove of relevance in the case of households of children with likely unauthorized parents, as many of them might not apply for such benefits owing to their undocumented status (Watson 2014). Nevertheless, to address these potential limitations, we also consider alternative measures, including a dummy variable indicative of whether the household's income falls below 1.5 times the poverty line, the logarithm of real household income and the household's participation in the Food Stamp program.

In addition to information on household poverty, the ACS contains rich sociodemographic information that can play a decisive role in understanding children's poverty exposure, such as the number of years parents have lived in the United States. But key to our analysis is the fact that the ACS consistently identifies the geographic location of households at a fine level, allowing us to exploit the geographic and temporal variation of immigration policies. Specifically, the area of analysis in the ACS is the Consistent Public Use Microdata Area (CONSPUMA), which contains several towns, cities and counties. In total, there are 543 geographic local areas (CONSPUMAs) covering the entire United States.

For the purpose of the study, we use a sample of 150,141 mixed-status families where at least one parent is likely unauthorized and at least one of the children living in the household is a U.S. born. ${ }^{13}$ As in all official representative datasets the ACS does not contain information on the migrant's legal status. We thus follow the economics literature and rely

\footnotetext{
${ }^{13}$ In addition, as a robustness check, we also experiment with using all households with at least one likely unauthorized parent, regardless of children's citizenship. Results prove robust to the usage of this alternative sample.
} 
on Hispanic ethnicity and lack of citizenship as a good proxy for likely unauthorized status (see Passel and Taylor 2010; Passel and Cohn 2011). Using this proxy yields a reasonable estimate of the likely unauthorized population in the United States. For example, we have $12,791,033$ likely unauthorized immigrants in 2013 , which is very close to the $11,010,000$ likely unauthorized immigrants estimated by the Center for Migration Studies. ${ }^{14}$ In our robustness checks, we also experiment with alternative definitions of our sample to more accurately capture the population who is unauthorized. Results prove robust to the use of these alternative sample definitions.

Table 1 presents some summary statistics for our sample. About 32 percent of households live in poverty - a share that rises to 54 percent when we consider a broader definition of poverty. Average household income for these households in 1999 constant dollars amounts to $\$ 24,100$ over the period under consideration, and 22 percent of households participated in the Food Stamps program. Importantly, Table 1 underscores some household traits likely correlated to poverty. Specifically, 24 percent of households in our sample are single headed, and only 17 percent of them have a household head with more than a High School diploma. Approximately 47 percent of household heads do not speak English at all or do not speak it well, even though, on average, they have resided in the United States for approximately 13 years. Still, the vast majority works (76 percent of them). And, on average, they are 35 years old and have roughly two children living in the household. The descriptive statistics in Table 1 also inform about some average characteristics of the CONSPUMAs where these households reside. Unemployment rates in those CONSPUMAs averaged 8 percent over the time period under consideration and, back in 1980, the share of low-skilled workers in sectors more likely to hire unauthorized workers was not that

\footnotetext{
${ }^{14}$ Estimates are available at http://cmsny.org/researchprojects/democratizingdata/tables/: "Estimates are shown for unauthorized population sizes of 1,000 or more. All of the estimates are rounded to 1,000s. The sum of the numbers for the countries is not likely to agree with the U.S. totals because estimates of fewer than 1,000 are not included in the table."
} 
different, fluctuating between 69 percent in manufacturing and 78 percent in services. To conclude, the share of the electorate voting for Republican candidates for the U.S. House of Representatives in the states to which the CONSPUMAs belonged averaged 46 percent $^{15}$

\subsection{Enforcement Data}

We gather data on the implementation of the following interior immigration enforcement initiatives: local and state level 287(g) agreements with ICE, local participation in Secure Communities, state level E-Verify mandates and omnibus immigration laws. Specifically, data on the $287(\mathrm{~g})$ agreements signed at either the local or state level is gathered from ICE's 287(g) Fact Sheet website (U.S. Immigration and Customs Enforcement 2015) and from Amuedo-Dorantes and Puttitanun (2014), and Kostandini et al. (2013). Data on participation in Secure Communities program is gathered from the 2013 ICE's Activated Jurisdictions document, which contains detailed information on the rollout of the Secure Communities program across counties in the United States between 2008 and 2013 (U.S. Immigration and Customs Enforcement 2013). Information on the implementation dates of E-Verify mandates and omnibus immigration laws is gathered from the National Conference of State Legislatures' website (Legislatures 2017).

Immigrant families in a given CONSPUMA may be exposed to a multiplicity of immigration enforcement measures, which may vary in different months in any given year. For example, someone residing in Etowah county, Alabama, in 2009 was exposed to a local $287(\mathrm{~g})$ jail enforcement program adopted by the Etowah county's sheriff office and a $287(\mathrm{~g})$ task force program adopted by the Department of Public Safety of Alabama. Following Watson (2013) and Amuedo-Dorantes and Lopez (2015), we first calculate an index between 0 and 1 of enforcement intensity $E I^{k}{ }_{m t}$ for each enforcement initiative $k$ (i.e.: 287(g) local,

\footnotetext{
${ }^{15}$ Detailed information on the various variables can be found in Appendix B.
} 
287(g) state, secure communities, Omnibus immigration law and E-verify), in a given MSA $m$, in a given year $t$ as:

$$
E I^{k}{ }_{c t}=\frac{1}{N_{m, 2000}} \sum_{c \in \boldsymbol{m}}^{m} \frac{1}{12} \sum_{j=\mathbf{1}}^{12} \mathbf{1}\left(E_{j, c}\right) P_{c, 2000}
$$

where $\mathbf{1}\left(E_{j, c}\right)$ is an indicator function that informs about the implementation of measure $k$ in county $c$ in month $j$ during the year in question, $P_{c, 2000}$ is the population of county $c$ according to the 2000 Census -that is, prior to the rolling of the enforcement initiatives being considered; and $N_{m, 2000}$ is the total population in the CONSPUMA.

We then calculate the total enforcement to which a household living in CONSPUMA $c$ and year $t$ is exposed to as the sum of all the individual indexes $E I_{c, t}^{k}$ as:

$$
\text { Total Enforcement }{ }_{c, t}=\sum_{k \in K}^{K} E I_{c, t}^{k}
$$

As shown in Table 1, the interior immigration enforcement index over the time period under consideration averaged 0.37 and fluctuated between 0 (i.e. no enforcement) and 4.18. And while, on average, local and state level immigration enforcement measures seem to be equally dominant, police-based measures were, without a doubt, more prevalent than employment-based measures.

To provide a sense of the evolution of interior immigration enforcement during the period under consideration, Panels A-C in Figure 1 shows the roll out of immigration enforcement measures over that time span. Lighter colors correspond to lower levels of enforcement (captured by the interior immigration enforcement index $E I_{c, t}$ ) in CONSPUMA $c$ in year $t$. Enforcement levels in the United States increased almost ten-fold during this period. In the first year of our sample, only 25 CONSPUMAs had an enforcement index greater than zero, whereas the majority of CONSPUMAs (515) had an enforcement index equal to 0 (i.e., no enforcement). By 2007, the number of CONSPUMAs without any interior immigration enforcement had dropped to 476 and, by 2010, to 255 . In addition, the intensity of immigration enforcement in many CONSPUMAs with some existing measure in place 
increased over time. The CONSPUMAs experiencing the largest increase in interior immigration enforcement during this period were located in Virginia, North Carolina, California and Utah. In contrast, CONSPUMAs located in states like North Dakota, Maine, Indiana or Wyoming did not experience an increase in enforcement regulation over this period, and their enforcement levels were still fairly low in 2010. The CONSPUMAs in Florida were the only ones whose immigration regulation eased up during this time, although they started off with a relatively high regulatory environment.

Because, depending on their scope and design, one can foresee a differential impact of the interior immigration enforcement initiatives examined, we also experiment with grouping the indexes in various ways. Specifically, we distinguish between employment-based immigration enforcement initiatives (exemplified by employment verification mandates applied by employers), and what we refer to as police-based measures (as in the case of 287(g) programs, Secure Communities and state omnibus immigration laws that involve the participation of the local or state police). In other instances, the indexes are grouped according to the geographic scope of the measures in place so as to distinguish between local level initiatives -as in the case of most $287(\mathrm{~g})$ agreements and participation in the Secure Communities program, and state level ones -as would be the case with a few state level 287(g), E-Verify mandates and omnibus immigration laws.

\section{Methodology}

To examine the impact of intensified interior enforcement on the probability that household income falls below the poverty line for households with a U.S. born child and a likely unauthorized parent, we first exploit the geographic and temporal variation in interior enforcement measures. In Section (5), we further take into account the potential endogeneity of the enforcement polices and the self-selection of immigrants into particular locations. Our benchmark specification is given by: 


$$
y_{h, c, t}=\alpha+\beta_{1} E I_{c, t}+X^{\prime}{ }_{h, c, t} \beta_{2}+Z^{\prime}{ }_{c, t-1} \beta_{3}+\gamma_{c}+\theta_{t}+\gamma_{c} t+\varepsilon_{h, c, t}
$$

where $y_{h, c, t}$ is a dummy variable indicative of whether income for household $h$, in CONSPUMA $c$ in year $t$ was below the poverty line. Standard errors are clustered at the CONSPUMA level. ${ }^{16}$

The enforcement index in CONSPUMA $c$ and time $t\left(E I_{c, t}\right)$ is our key regressor. As noted earlier, it captures the intensity of local and state level immigration enforcement in CONSPUMA $c$ at time $t$. Our coefficient of interest is $\beta_{1}$, which captures the relationship between the intensity of immigration enforcement and the household's income and poverty exposure. A positive coefficient would be consistent with the hypothesis that tougher enforcement increases the economic difficulties experienced by the families of U.S. born children with likely unauthorized parents.

Additionally, equation (2) includes the vector $X_{h, c, t}$, which accounts for a range of household characteristics known to be potentially correlated with household income and poverty exposure. The latter include dummy variables for whether the household is a single headed household, as well as indicators for the age, lack of English proficiency, educational attainment, employment and years of U.S. residency of the household head, and information on the number of children residing in the household.

Equation (2) also incorporates some local (at the CONSPUMA and state levels) timevarying characteristics measured one year prior. Specifically, the vector $Z$ includes information on the CONSPUMA unemployment rate, which can affect household income and its exposure to poverty. Additionally, to purge the estimated coefficient from the role of local political tendencies of the electorate, the vector $Z$ also incorporates information on the share of the state's electorate voting Republican in the last congressional elections.

\footnotetext{
${ }^{16} \mathrm{We}$ also experiment with clustering the standard errors at the broader state level. Results prove robust to this alternative clustering.
} 
To conclude, equation (2) also includes geographic and temporal fixed-effects, as well as area-specific time trends. The geographic fixed-effects $\left(\gamma_{c}\right)$ address unobserved and timeinvariant CONSPUMA-specific characteristics potentially correlated with household income and the household's exposure to poverty, as could be the case if the household resides in an economically depressed area. The temporal fixed-effects, captured by $\theta_{t}$, account for aggregate level shocks potentially impacting poverty, as could have been the case with the 2008-2009 downturn. Finally, the CONSPUMA-specific trends allow us to control for the impact of unobserved time-varying local traits potentially correlated to the outcome of interest and not captured in the vector $Z$.

\section{Tougher Immigration Enforcement and Children's Economic Resources}

\subsection{Main Findings}

The results from estimating equation (2) using ordinary least squares on the sample of households with U.S. born children and, at least, one undocumented parent are displayed in the first four columns of Table 2. We estimate a number of specifications that progressively add controls. According to the estimates in the fourth and most complete model specification in Table 2, a one standard deviation increase in the immigration enforcement index raises the poverty exposure of households in our sample by 1.3 percentage points or 4 percent. $^{17}$

The remaining coefficient estimates in Table 2 look as expected. For example, residing in a single headed household raises the likelihood of living in poverty by 25 percentage points. Similarly, having a household head who does not speak English or does not speak it well raises the likelihood of household poverty by 11 percentage points. The number of children in the household also matters, with each additional child raising the likelihood of life in poverty by close to 7 percentage points. In contrast, having a household

\footnotetext{
${ }^{17}$ According to the descriptive statistics in Table 1, the standard deviation of the enforcement index is $0.64-$ about twice the average share of children living below the poverty line, which is 0.32 or 32 percent.
} 
head who is older, more educated, employed or a long-time resident of the United States significantly lowers the poverty risk.

Because some of the intensification of immigration enforcement occurred during the 2008-2009 recessionary years, one might be concerned about the possibility that the measured impact is capturing the effects of the economic downturn on poverty. Note that, if that were the case, we should be able to see similar effects on other groups of Hispanic households; even if the parents are naturalized and, therefore, should not have been negatively impacted by the intensification of immigration enforcement. Table 3 presents the coefficients from estimating equation (2) on a sample of naturalized Hispanic households with at least one U.S. born child between 0 and 18 years of age living in the household during this period. Table 4 presents the coefficients from estimating equation (2) on a sample of native Hispanic households with at least one U.S. born child between 0 and 18 years of age living in the household. In both cases, regardless of the model specification being used, we find no evidence of a significant impact of immigration enforcement on the poverty exposure of these families. This is true even after accounting for a range of economic characteristics, year and county fixed-effects, as well as county-specific time trends capturing the impact of the economic downturn or the differential county recovery from the latter. Furthermore, despite the differential impact of immigration enforcement, other poverty determinants across Tables 2, 3 and 4 remain similar.

\subsection{Robustness Checks}

We next perform a number of robustness checks to assess the sensitivity of our findings to the use of: (1) alternative measures of household poverty, (2) alternative definitions of who is considered a likely unauthorized parent, and (3) alternative samples that exclude recessionary years or counties identified as outliers with regards to their 
implementation of immigration enforcement. Overall, the robustness checks in Tables 5, 6 and 7 reveal that our results are qualitatively and quantitatively the same.

Specifically, Table 5 displays our findings using alternative measures of household poverty. As noted earlier on, a common criticism is that the official poverty level is too low and that, on average, families need an income of about twice the federal poverty level just to afford basic expenses (Bitler et al. 2014). Therefore, in Table 5, we experiment with using as dependent variables: (a) a dummy equal to 1 if the household had an income that fell below 1.5 times the poverty line (Panels A); (b) the logarithm of real household income (Panel B), and (c) a dummy equal to 1 if the household participated in the Food Stamps program (Panel C). Our results prove rather consistent to the use of alternative proxies of household poverty or lack of economic resources. Focusing on the most complete specification, a one standard deviation increase in immigration enforcement leads to increases in the likelihood that household income is below 1.5 times the poverty line of 1.3 percentage points or 2.3 percent. Similarly, the same increase in immigration enforcement lowers household income by 19 percent and raises the likelihood of participation in the Food Stamps program by 1.5 percentage points or 7 percent. In contrast, none of these impacts are observed when we look, instead, at similar families where the parents are naturalized (Panel B) or native (Panel C).

We also experiment with using alternative definitions of who might be considered a likely undocumented parent. In Panel A of Table 6A, we focus on families of U.S. born children with at least one likely unauthorized parent, where the latter is defined as a Hispanic non-citizen parent who has been living in the United States for 5 years or more. Doing so addresses any concerns regarding the possibility of including immigrants with non-immigrant visas among our sample of likely undocumented parents. After all, most non-immigrant visas are granted for relatively short periods of time. Next, in Panel B, we consider households of 
U.S. born children with a parent who is a Hispanic non-citizen with less than a high school diploma - a trait characteristic of most undocumented immigrants in the United States (Passel and Cohn 2011). Finally, in Panel C, we focus on families of U.S. born children with at least one likely unauthorized parent, where the latter is defined as a Hispanic non-citizen parent who is less than 45 years of age. This eliminates individuals who might have legalized under the 1986 Immigration Reform and Control Act. In all panels, we continue to find alike results. Namely, a one standard deviation increase in immigration enforcement raises the likelihood of life in poverty for these sets of households by approximately 1.8 percentage points ( 6 percent), 1.9 percentage points ( 5 percent), and 1.3 percentage points (4.2 percent), respectively. Furthermore, none of these aforementioned effects are statistically different from zero when we repeat the exercise focusing on households headed by naturalized or native parents in Table 6B.

Finally, in Table 7, we check the robustness of our results to various sample restrictions. In Panel A, we first display the results excluding the year 2009 -a recessionary year in the United States when poverty significantly rose. In Panel B, we re-estimate our models excluding Maricopa County -clearly an outlier with regards to immigration enforcement. Lastly, in Panel C, we experiment with using all households with children between 0 and 18 years old where at least one parent in unauthorized, independently of the children's citizenship status. In all instances, we continue to find a similar impact of intensified immigration enforcement on the poverty exposure of households of American children with an undocumented parent. ${ }^{18}$

\subsection{Identification and Falsification Tests}

\footnotetext{
${ }^{18}$ Specifically, a one standard deviation in immigration enforcement raises the poverty exposure of households in Panel A by 1.4 percentage points (4.5 percent), of those in Panel B by 1 percentage point ( 3 percent), and of households in Panel $\mathrm{C}$ by 1 percentage point (3.5 percent).
} 
The validity of our findings depends on a number of assumptions. In this section, we refer to each one of these assumptions and explore whether they seem to be fulfilled in our case. 


\subsubsection{Testing for Parallel Trends Assumptions}

Thus far, the analysis has assumed that poverty trends prior to the intensification of interior immigration enforcement of households of U.S. born children with a likely unauthorized parent were the same in areas with and without tougher immigration enforcement prior to the implementation of stricter measures in the latter group. To that end, we estimate equation (4a), which contains a full set of year dummies going from four years before the enforcement index turns positive, as follows:

$y_{h, c, t}=\alpha+\sum_{i=-4}^{-1} \phi_{i} D_{c, i}+\beta_{1} E I_{c, t}+X_{h, c, t}^{\prime} \beta_{2}+Z_{c, t-1}^{\prime} \beta_{3}+\gamma_{c}+\theta_{t}+\gamma_{c} t+\varepsilon_{h, c, t}$

where $D_{c, i}$ is a vector of dummies for the $i$ th year before the enforcement index first turns positive in each CONSPUMA. In the absence of any pre-existing differential poverty trends between regions with different immigration enforcement levels, the coefficients on the vector of dummies $D_{c, i}$ should not be statistically different from zero. As shown in Table 8A, only the coefficient on the immigration enforcement index is statistically different from zero and similar in magnitude to the one in Table $2,{ }^{19}$ suggesting that the lack of any anticipation impacts.

Note, however, that a more relevant question is whether the observed impact of immigration enforcement on household poverty was unique to mixed-status households in our sample, or if it was also experienced by households of other American children headed by otherwise similar naturalized or native parents. To assess whether that is the case, we reestimate equation (4a) on a pooled sample of treated and control households. Specifically, as show in equation (4b), we interact the vector of year dummies with a dichotomous variable indicative of whether the household is one with likely unauthorized parents $\left(L U_{h}\right)$ as follows:

\footnotetext{
${ }^{19}$ A one standard deviation increase in immigration enforcement raises the household's propensity to life in poverty by 1.5 percentage points or 4.8 percent.
} 


$$
\begin{gathered}
y_{h, c, t}=\alpha+\sum_{i=-4}^{-1} \phi_{i} D_{c, i}+\sum_{i=-4}^{-1} \varphi_{i} D_{c, i} * L U_{h, c, t}+\pi_{1} E I_{c, t} L U_{h}+\psi L U_{h, c, t}+\beta_{1} E I_{c, t}+ \\
X_{h, c, t}^{\prime} \beta_{2}+Z_{c, t-1}^{\prime} \beta_{3}+\gamma_{c}+\theta_{t}+\gamma_{c} t+\varepsilon_{h, c, t}
\end{gathered}
$$

where as before $D_{c, i}$ is a vector of dummies for the $i$ th year before $(-i)$ or after $(i)$ the enforcement index first turns positive. In the absence of any pre-existing differential poverty trends between treated and control households, the estimated coefficients $\varphi_{i}$ on the interaction terms corresponding to the years prior to the activation of tougher enforcement should not be statistically different from zero.

The results from this exercise are displayed in Table 8B. None of the coefficients on the interaction terms for the years preceding the implementation of tougher immigration enforcement are statistically different from zero. The positive impact of intensified enforcement on the poverty exposure of families with U.S.- born children and, at least, one likely unauthorized parent, does not emerge until the measures were implemented. As such, there is no evidence of a differential pre-trend in the incidence of poverty among households of U.S. born children with a likely unauthorized parent and households of U.S. -born children with naturalized parents. Furthermore, the impact of intensified immigration enforcement continues to be statistically significant despite the inclusion of placebo terms leading to its implementation, with a one standard deviation increase in the enforcement raising the household's poverty exposure by 6.2 percent -an impact remarkably persistent 4 years later.

\subsubsection{Addressing Endogeneity Concerns}

Another potential concern with the estimates in Table 2 refers to the potential endogeneity of interior immigration enforcement with respect to the incidence of poverty. As with most policies, endogeneity can stem from two sources, including: (1) the non-random adoption of enforcement measures by CONSPUMAs, as well as (2) the non-random residential choices made by unauthorized immigrants, who might prefer to settle in 
CONSPUMAs with lesser enforcement. In both instances, the level of interior immigration enforcement to which the migrant is exposed to would not be exogenously determined. To address this concern, we perform a couple of identification tests.

First, we assess if the implementation of tougher interior immigration enforcement, even if not random, is uncorrelated to the incidence of poverty among households of U.S. born children with a likely unauthorized parent prior to the implementation of tougher immigration enforcement -as needed for identification purposes. To assess if that is a valid assumption, we follow La Ferrara et al. (2012) and aggregate the data at the CONSPUMA level to estimate the following model:

$$
\text { EI Year }{ }_{c}=\alpha+X_{c}^{\prime 2000} \alpha+Z_{c}^{\prime 2000} \mu+\lambda W_{c}^{2000}+\varepsilon_{c}
$$

where $E I \mathrm{Year}_{c}$ is the first year when the enforcement index turned positive in CONSPUMA $c$, and $X_{c}^{2000}$ are the same vectors of household characteristics in equation (3) aggregated at the CONSPUMA level, thus reflecting average CONSPUMA characteristics before any measure came into effect, i.e. in the year 2000. We also control for $Z_{c}^{2000}$, which contains the CONSPUMA unemployment rate in 2000, the CONSPUMA share of low-skilled workers employed in various sectors in 2000 , and the share voting Republican in the state to which each CONSPUMA belongs in 2000. Most importantly, the vector $W_{c}^{2000}$ is the share of Hispanic families living in poverty in each CONSPUMA in 2000. We estimate equation (5) with and without Metropolitan Statistical Area (MSA) fixed-effects. The errors are being clustered at the MSA level. In the absence of selection effects, we should find that the coefficient $\lambda$ is not statistically different from zero.

Table 9 presents the results from that exercise. Regardless of the specification being used, we fail to see any statistically significant relationship between poverty levels in the CONSPUMA from prior to the implementation of tougher immigration enforcement and the timing of tougher immigration enforcement. In other words, CONSPUMAs with higher 
poverty rates among households of U.S.- born children with a likely unauthorized parent do not appear to have self-selected themselves into tougher immigration enforcement. ${ }^{20}$

Secondly, we explore the possibility that our results might be biased by the potentially endogenous location of migrants. One could imagine that households with, at least, one likely unauthorized parent would be sensitive to immigration enforcement due to fear of deportation. Because migrants, especially unauthorized ones, are a relatively mobile population, they are likely to move in response to the adopted enforcement measures. For example, there are reports indicating that the enactment of HB56 in Alabama -Alabama's omnibus immigration law- resulted in the overnight flight of many Hispanic children from its public schools and created serious concerns among school administrators. ${ }^{21}$ For example, if poorer undocumented immigrants move to locations with less immigration enforcement, we might not find a statistically significant impact of intensified immigration enforcement on household incomes or their exposure to poverty. ${ }^{22}$

To address this limitation, we instrument for households' non-random exposure to immigration enforcement using information on what their exposure would have been had they chosen to reside in the same locations chosen by their countrymen prior to the escalation

\footnotetext{
${ }^{20}$ We repeat the same exercise using, instead, the level of immigration enforcement at the CONSPUMA once it adopts tougher measures as the dependent variable. As shown in Table C.1 in the appendix, the incidence of poverty among households in our sample did not help predict the intensity of immigration enforcement introduced in the CONSPUMA either.

${ }^{21}$ See http://neatoday.org/2011/08/31/alabama-schools-worry-about-effects-of-immigration-law/

${ }^{22}$ Program-induced migration has long been acknowledged to bias policy estimates. For example, Moffitt (1992) describes how program-induced migration tends to make generous welfare programs look worse for labor supply than they really are, as poor people who would in any case have weak labor force attachment might move to states with more generous welfare benefits.
} 
of interior immigration enforcement. ${ }^{23}$ To that end, we use construct the following "shiftshare" instrument: ${ }^{24}$

$I V_{c, o, t}=$ Share of Undocumented Immigrant Imo,1980 $*$ Enforcement Index $_{c, t}$

The shift is the policy itself (i.e. Enforcement Index ${ }_{c, t}$ ), which we first examine to make sure it is uncorrelated to pre-existing poverty levels among mixed-status households. The share addresses the non-random location of mixed-status households using information on the residential distribution of households headed by likely undocumented countrymen prior to the implementation of any immigration enforcement. That is, in the spirit of other studies in the immigration literature (e.g. Bartel 1989; Altonji and Card 1991; Card 2001; Cortés and Tessada 2011 among many others), we exploit the entrenched tendency of immigrants to locate in areas where they have networks of countrymen to instrument for their non-random residential choices. Because the earliest adoption of the interior immigration enforcement initiatives being examined did not occur until 2002 by the state of Florida, we look at where likely unauthorized parents chose to reside back in 1980. In that manner, we address any concerns regarding the role that economic conditions not captured by the CONSPUMA unemployment rates, fixed-effects or specific time trends could be playing in determining the location of the household and how well it does economically. The Share of Undocumented Immigrant I $, 0,1980$ is given by the share of likely unauthorized migrants from country of origin $o$ residing in CONSPUMA $c$ in the 1980 Census as given by:

$$
\text { Share of Undocumented Immigrant } \text { I }, 0,1980=\frac{\text { undocumented } \text { immigrants }_{c, 0,1980}}{\text { undocumented } \text { immigrants }_{0,1980}}
$$

\footnotetext{
${ }^{23}$ It is worth noting that, despite the emergence of new immigrant locations during the 1990s, the vast majority of immigrants continued to locate in traditional states that accounted for approximately $60 \%$ of the unauthorized population: California, Texas, Florida or New York/New Jersey and Illinois (see: http://www.pewresearch.org/fact-tank/2016/09/20/5-facts-about-illegal-immigration-in-the-u-s/).

${ }^{24}$ Shift-share instruments have been widely used in the economics literature in a variety of contexts (see, for example: Bartik 1991; Nakamura and Steinsson 2014; Wilson 2012; Autor, Dorn, and Hanson 2013; Kovak 2013; Nunn and Qian 2014 to name a few).
} 
Table 10 displays the estimates from our shift-share instrument. The last row confirms that the IV is a good instrument. Focusing on the most complete model specification in column (4), we find that the F-stat from the first stage regression is equal to 40.36 -thus, larger than the recommended size of 10 (Stock and Yogo 2005). Additionally, the positive and highly statistically significant IV coefficient from the first stage regression confirms the entrenched tendency for immigrants to locate in areas with established networks of their countrymen. Finally, the estimates from the second stage regression closely match those in Table 2. A one standard deviation increase in the new enforcement level to which households in our sample would be exposed to had they located following historical residential patterns (equal to 0.13 ) would raise their likelihood of life in poverty by 1.3 percentage points or 4 percent. As a result, the estimates in Table 2 do not seem be significantly biased.

Still, as an additional test for any potential biases in our estimates resulting from the endogenous location of undocumented migrants, we re-estimate our model in equation (4) using, exclusively, data on families who report not moving over the past year. As such, their location choice is less likely to be contaminated by immigrants' potential responsiveness to the toughening of immigration enforcement. The estimates in Table C.2, Appendix C, reveal a poverty impact similar to the one measures in Table 2, suggesting that our estimates are not significantly biased by the potentially endogenous residential location of undocumented immigrants.

\section{Understanding the Impact of Intensified Immigration Enforcement on Poverty}

Thus far, we have established that the intensification of interior immigration enforcement significantly lowered household income and raised the poverty exposure of households with U.S. born children and a likely unauthorized parent. In this section, we first identify the type of immigration enforcement policy responsible for the measured policy 
impacts. Subsequently, we investigate the channels or mechanisms through which those impacts are likely taking place.

\subsection{Policy Channels}

From a policy perspective, it is crucial to gain a better understanding of the type of enforcement policy most likely responsible for the found poverty impacts. To that end, we distinguish between what we refer to as 'employment-based' policies -namely, those involving work eligibility checks by employers as in the case of employment verification mandates, and 'police-based' policies involving the local or state police. Similarly, we distinguish policies according to their geographic scope classifying them into local measures and state-level measures.

According to the estimates in the most complete specification in Panel A of Table 11, police-based measures -directly linked to the detention and deportation of undocumented immigrants- are mainly responsible for the rising poverty exposure of households with U.S. born children and a likely unauthorized parent. Specifically, a one standard deviation increase in such measures (equal to 0.45 ) raises their likelihood of life in poverty by 1 percentage point or 3 percent. The effect of employment-based measures, exemplified by state level employment verification mandates, is estimated less precisely and is not statistically different from zero at conventional levels, although the magnitude of the coefficient is similar.

Consistent with these results, the estimates in Panel B reveal that local policies (all of which are police-based measures) are the most relevant in impacting households' poverty exposure. In particular, a one standard deviation increase in local level enforcement (approximately 0.27 ) raises the likelihood of life in poverty by approximately 1 percentage point or 2.5 percent. However, the impact of intensified immigration enforcement initiatives 
at the state level is not statistically different from zero at conventional levels. Testing reveals that the impacts of state and local policies are statistically different from each other.

The findings in Panels A and B of Table 11 are not surprising and seem consistent with the weak effects of employment restrictions on immigrants' earnings after the implementation of tougher immigration laws found in the literature (see Table A.1). The vast majority of unauthorized immigrants are employed in the underground or informal economy, where the use of E-Verify is null -as would be the case with women working as nannies and housekeepers, or with self-employed men working as handymen or gardeners. In other instances, unauthorized migrants work in sectors that are exempted from the use of E-Verify -as would be the case with private sector firms in the most common instance of a mandate that refers to public sector employers or contractors. And, even in the more unique case of having a universal employment verification mandate to which private sector firms need to comply with, a number of employees are excluded from the use of E-Verify if they are hiring on relatively short-term contracts (as in agriculture and construction) or are small businesses with fewer than 10 employees (as it is often the case in the retail food \& drink sector). Lastly, even if employment verification mandates restrict the employment and lower the earnings of unauthorized immigrants, many of them reside in mixed-status households $-\mathrm{a}$ fact that can help palliate the negative impact on the overall household's exposure to poverty.

Compared to employment-based measures, police-based enforcement measures involve the local and state-police in their implementation and have led to the identification of more than 373,800 potentially removable aliens between January 2006 and September 2014 (U.S. Immigration and Customs Enforcement 2015). More than 1.8 million unauthorized immigrants, typically male household heads, have been deported during the Administration of President Barack Obama alone (Vaughan 2013), with that number rising to more than 4.5 million since the U.S. Congress passed the Illegal Immigration Reform and Immigrant 
Responsibility Act in 1996 (IIRIRA) (Bergeron and Hipsman 2014). In sum, police-based enforcement measures, which are directly linked to deportations and deportations fears, not surprisingly result in worse economic outcomes for families of likely undocumented immigrants.

\subsection{Mechanisms}

The analyses in Table 11 underscore the importance that police-based enforcement has had on the poverty exposure of households with U.S. born children with a likely undocumented parent. As such, it becomes apparent that, despite the economic damage inflicted by employment restrictions inherent in employment verification mandates on likely undocumented individuals of working-age, employment-based measures do not seem to play a determining role in the household's poverty risk. Rather, police-based measured, more directly associated to deportations and deportation fears, do.

To further disentangle whether the impact of police-based immigration enforcement is materializing via the deportation of a household head and/or via deportation fears, we first reestimate equation (3) for a sample of intact households in which both partners are present in the household. If our results were simply driven by those cases in which one of the household heads has been deported, we should find no effect of intensified enforcement on the likelihood of life in poverty among intact households. According to the estimates in Panel A of Table 12, the impact of intensified immigration enforcement is present even among intact households. Hence, in addition to the direct damage that the deportation of a household head might have on the economic well-being of the household, fear of deportation is also likely playing a significant role. Perhaps, these households, fearing apprehension, start living in the shadows -a decision that ultimately impacts their employment choices and their poverty exposure. 
In sum, the estimates in Tables 11 and 12 suggest that police-based measures, particularly those at the local level, are the ones driving the observed negative impacts of intensified immigration enforcement on the poverty risk endured by households of U.S. born children with a likely unauthorized parent. We explore whether this economic damage is present, as well, as among intact households not suffering the deportation of a household head. We find that even these households prove vulnerable -suggesting that deportation fears alone might be sufficient for the household to endure economic hardship. This finding also uncovers one of the likely mechanisms through which deportation fears inherent in policies associated to numerous apprehensions and expulsions operate -namely, by inducing likely unauthorized individuals to live in the shadows and minimize their exposure to the police.

\section{Conclusions}

The past two decades have witnessed an escalation of interior immigration enforcement at both the local and state levels. Using data from the American Community Survey (ACS) and an enforcement index created using novel data on a wide range of state level and local immigration enforcement initiatives, we explore the impact that intensified enforcement has had on the poverty risk of families of U.S. born children with likely unauthorized parents. We find that tougher enforcement is associated with lower family income and a higher probability of life in poverty, with most of the impact originating from local police-based measures, such as $287(\mathrm{~g})$ agreements and the Secure Communities program. Our results prove robust to a number of identification and robustness checks, and suggest that deportations and deportation fears, rather than work eligibility mandates, are mainly responsible for the increases in poverty.

We also shed light onto the types of immigration laws that may affect households' economic resources more negatively. We document that police-based measures, particularly those at the local level, are the ones driving the observed negative impacts of intensified 
immigration enforcement on the poverty risk endured by households of U.S. born children with a likely unauthorized parent. We also uncover that this economic damage is also observable among intact households -suggesting that deportation fears alone might be sufficient for the household to endure economic hardship. This impact might possibly be taking place through a reduction in the work hours of working-age likely unauthorized men.

Recent work by Bailey et al. (2014), Bitler et al. (2014) and Peri (2013) shows that child poverty drops with increased availability of family planning programs and higher unemployment rates, but it is independent of immigration shocks. We show that intensified immigration enforcement affects the exposure to poverty of many mixed-status households as in the case of households headed by an undocumented parent with at least one U.S. born child. Immigration enforcement was responsible for about $1 / 8$ of the overall increase in poverty (32 percent) among those households over the analyzed period. Given the relationship between early economic resources and later life outcomes, the findings call for further research into the unintended consequences of an expanding piecemeal approach to immigration enforcement on future generations of Americans and on the social and economic fabric of the United States. 


\section{References}

Almond, Douglas, and Janet Currie. 2011. "Human Capital Development before Age Five." In Handbook of Labor Economics, edited by eds In O. Ashenfelter and D.Card, 13151486. Maryland Heights, MO:Elsevier.

Altonji, Joseph, and David Card. 1991. "The Effects of Immigration on the Labor Market Outcomes of Less-Skilled Natives." In Immigration, Trade, and the Labor Market, 20134. National Bureau of Economic Research, Inc.

Amuedo-Dorantes, Catalina, and Cynthia Bansak. 2012. "The Labor Market Impact of Mandated Employment.” American Economic Review: Papers \& Proceedings 102 (3): 543-48.

Amuedo-Dorantes, Catalina, and Mary J Lopez. 2015. "Falling Through the Cracks? Grade Retention and School Dropout among Children of Likely Unauthorized Immigrants." American Economic Review: Papers \& Proceedings 105 (5): 598-603.

Amuedo-Dorantes, Catalina, and Thitima Puttitanun. 2014. "Remittances and Immigration Enforcement." IZA Journal of Migration 3:6. doi:10.1186/2193-9039-3-6.

Amuedo-Dorantes, Catalina, Thitima Puttitanun, and Ana P Martinez-Donate. 2013a. "How Do Tougher Immigration Measures Affect Unauthorized Immigrants?" Demography 50 (3): 1067-91. doi:10.1007/s13524-013-0200-x.

_ 2013b. "How Do Tougher Immigration Measures Affect Unauthorized Immigrants?" Demography 50 (3): 1067-91. doi:10.1007/s13524-013-0200-х.

Autor, D.H, D. Dorn, and G.H. Hanson. 2013. "The China Syndrome: Local Labor Market Effects of Import Competition in the United States." American Economic Review 103 (6): $2121-68$.

Bailey, M. J., O. Malkova, and J. Norling. 2014. "Do Family Planning Programs Decrease Poverty? Evidence from Public Census Data." CESifo Economic Studies 60 (2): 312-37. doi:10.1093/cesifo/ifu011.

Bailey, Martha J, and Susan M Dynarski. 2011. "Gains and Gaps: Changing Inequality in U.S. College Entry and Completion.” NBER Working Paper Series 17633.

Bailey, Martha J, Olga Malkova, and Johannes Norling. 2014. "Do Family Planning Programs Decrease Poverty? Evidence From Public Census Data." CESifo Economic Studies 60 (2): 312-37. doi:10.1093/cesifo/ifu011.

Bartel, Ann P. 1989. "Where Do the New U . S . Immigrants Live?" Journal of Labor Economics 7 (4): 371-91. doi:10.1086/298388.

Bartik, T. J. 1991. Who Benefits from State and Local Economic Development Policies? Kalamazoo, MI: W.E. Upjohn Institute for Employment Research.

Bergeron, Claire, and Faye Hipsman. 2014. "The Deportation Dilemma: Reconciling Tough and Humane Enforcement." Washington, DC. 
Bitler, Marianne, Hilary Hoynes, and Elira Kuka. 2014. "Child Poverty and the Great Recession." Under Review.

Bohn, Sarah, and Magnus Lofstrom. 2013. "Employment Effects of State Legislation against the Hiring of Unauthorized Immigrant Workers." In Immigration, Poverty, and Socioeconomic Inequality, edited by David Card and Steven Raphael. Russell Sage.

Bohn, Sarah, Magnus Lofstrom, and Raphael Steven. 2014. "Did the 2007 Legal Arizona Workers Act Reduce the States Unauthorized Immigrants?" The Review of Economics and Statistics 96 (2): 258-69.

Card, David. 2001. "Immigrant Inflows, Native Outflows, and the Local Labor Market Impacts of Higher Immigration.” Journal of Labor Economics 19 (1): 22-64.

Case, Anne, Darren Lubotsky, and Christina Paxson. 2002. "Economic Status and Health in Childhood: The Origins of the Gradient." American Economic Review 92 (5): 1308-34.

Cortés, Patricia, and José Tessada. 2011. "Low-Skilled Immigration and the Labor Supply of Highly Skilled Women.” American Economic Journal: Applied Economics 3 (3): 88123. doi:10.1257/app.3.3.88.

Ferrara, Eliana La, Alberto Chong, and Suzanne Duryea. 2012. "Soap Operas and Fertility: Evidence from Brazil." American Economic Journal: Applied Economics 4 (4): 1-31.

Kostandini, G., E. Mykerezi, and C. Escalante. 2013. "The Impact of Immigration Enforcement on the U.S. Farming Sector." American Journal of Agricultural Economics 96 (1): 172-92. doi:10.1093/ajae/aat081.

Kovak, B.K. 2013. "Regional Effects of Trade Reform: What Is the Correct Measure of Liberalization?” American Economic Review 103 (5): 1960-76.

Legislatures, National Conference of State. 2017. "State E-Verify Laws." http://www.ncsl.org/research/immigration/everify-faq.aspx\#2012 State Action.

Levine, Phillip B, and D.J Zimmerman. 2010. "Introduction to" Targeting Investments in Children: Fighting Poverty When Resources Are Limited." In Targeting Investment in Children: Fighting Poverty When Resources Are Limited, edited by Phillip B Levine and D.J Zimmerman, 3-11.

Meissner, D., D.M Kerwin, M. Chishti, and C. Bergeron. 2013. Immigration Enforcement in the United States : The Rise of a Formidable Machinery. Technical Report, Migration Policy Institute.

Miles, Thomas J., and Adam B. Cox. 2014. "Does Immigration Enforcement Reduce Crime? Evidence from Secure Communities." Journal of Law and Economics 57 (4). doi:10.1017/CBO9781107415324.004.

Moffitt, R. 1992. "Incentive Effects of the U.S. Welfare System: A Review." Journal of Economic Literature 30 (1): 1-61.

Nakamura, E., and J Steinsson. 2014. "Fiscal Stimulus in a Monetary Union: Evidence from US Regions.” American Economic Review 104 (3): 753-92. 
Nguyen, Mai Thi, and Hannah Gill. 2010. "The 287 ( G ) Program The Costs and Consequences of in North Carolina Communities." Vol. The Latino. doi:10.13140/RG.2.1.4129.5204.

Nunn, N, and N Qian. 2014. "US Food Aid and Civil Conflict." Amercian Economic Review $106(6)$.

Passel, Jeffrey S, and D’Vera Cohn. 2011. "Unauthorized Immigrant Population : National and State Trends , 2010." PewResearchCenter. Pew Hispanic Center. Washington, D.C.

Passel, Jeffrey S, D’Vera Cohn, and Molly Rohal. 2014. "Unauthorized Immigrant Totals Rise in 7 States, Fall in 14: Decline in Those From Mexico Fuels Most State Decreases." Washington, D.C. Pew Research Center's Hispanic Trends Project, November, Pew Research Center's Hispanic Trends Project, November, . Washington, DC.

Passel, Jeffrey S, and Paul Taylor. 2010. "Unauthorized Immigrants and Their U.S. Born Children." Washington, D.C.

Peri, Giovanni. 2013. "The Impact of Immigration on Native Poverty.” In Immigration, Poverty, and Socioeconomic Inequality, edited by David Card and Steven Raphael. National Poverty Center Series on Poverty and Public Policy.

Ruggles, Steven, Katie Genadek, Ronald Goeken, Josiah Grover, and Matthew Sobek. 2015. "Integrated Public Use Microdata Series: Version 6.0 [Dataset]." Minneapolis: University of Minnesota. doi:http://doi.org/10.18128/D010.V6.0.

Stock, James, and Motohiro Yogo. 2005. "Testing for Weak Instruments in Linear IV Regression." In Identification and Inference for Econometric Models: Essays in Honor of Thomas Rothenberg, Andrew DWK, 80-105. New York: Cambridge: Cambridge University Press.

U.S. Immigration and Customs Enforcement (ICE). 2013. "Fact Sheet: Delegation of Immigration Authority Section 287(g) Immigration and Nationality Act."

—. 2015. "Fact Sheets 287g." http://www.ice.gov/factsheets/287g.

Vaughan, Jessica M. 2013. "Deportation Numbers Unwrapped Raw Statistics Reveal the Real Story of ICE Enforcement in Decline." Center for Immigration Studies, no. October: 116.

Watson, Tara. 2013. "Enforcement and Immigrant Location Choice." NBER Working Paper Series 19626.

- 2014. "Inside the Refrigerator: Immigration Enforcement and Chilling Effects in Medicaid Participation." American Economic Journal:Economic Policy 6 (3): 313-38.

Wilson, D.J. 2012. "Fiscal Spending Jobs Multipliers: Evidence from the 2009 American Recovery and Reinvestment Act." American Economic Journal: Economic Policy 4 (3): 251-82.

Wong, Tom K. 2012. "287(g) and the Politics of Interior Immigration Control in the United States: Explaining Local Cooperation with Federal Immigration Authorities." Journal of 
Ethnic and Migration Studies 38 (5): 737-56. 
Table 1: Summary Statistics

\begin{tabular}{|c|c|c|c|c|c|}
\hline Descriptive Statistic: & Mean & S.D. & Min & Max & Observations \\
\hline \multicolumn{6}{|l|}{ Panel A: Poverty and Income Related Measures } \\
\hline Poverty 100 & 0.32 & 0.47 & 0.00 & 1.00 & 150,141 \\
\hline Poverty 150 & 0.54 & 0.50 & 0.00 & 1.00 & 150,141 \\
\hline Log Family income & 10.09 & 0.84 & 0.00 & 13.78 & 147,049 \\
\hline Food Stamp & 0.22 & 0.42 & 0.00 & 1 & 150,414 \\
\hline \multicolumn{6}{|l|}{ Panel B: Other Regressors } \\
\hline Single Headed HH & 0.24 & 0.43 & 0.00 & 1.00 & 150,141 \\
\hline HH Head with more than HS & 0.17 & 0.37 & 0.00 & 1.00 & 150,141 \\
\hline HH Head Does not Speak English & 0.47 & 0.50 & 0.00 & 1.00 & 150,141 \\
\hline Years in the U.S. for the HH Head & 13.37 & 9.57 & 0.00 & 65.00 & 150,141 \\
\hline Employed HH Head & 0.76 & 0.42 & 0.00 & 1.00 & 150,141 \\
\hline Age of the HH Head & 34.93 & 8.43 & 13.00 & 92.00 & 150,141 \\
\hline No. of Kids in the $\mathrm{HH}$ & 2.42 & 1.15 & 1.00 & 14.00 & 150,141 \\
\hline Unemployment Rate in CONSPUMA & 0.08 & 0.03 & 0.01 & 0.35 & 150,141 \\
\hline Share Voting Republican in State & 0.46 & 0.10 & 0.00 & 0.69 & 150,141 \\
\hline \multicolumn{6}{|l|}{ Panel C: Enforcement Index } \\
\hline Enforcement Index & 0.37 & 0.64 & 0.00 & 4.18 & 150,141 \\
\hline Local-level Enforcement & 0.19 & 0.27 & 0.00 & 1.48 & 150,141 \\
\hline State-level Enforcement & 0.19 & 0.52 & 0.00 & 3.00 & 150,141 \\
\hline Police-based Enforcement & 0.28 & 0.45 & 0.00 & 3.18 & 150,141 \\
\hline Employment-based Enforcement & 0.09 & 0.27 & 0.00 & 1.00 & 150,141 \\
\hline Enforcement Index Using Historical Residential Patterns & 0.05 & 0.13 & 0.00 & 2.09 & 150,141 \\
\hline
\end{tabular}

Notes: Sample: families with at least one U.S. born child ranging between 0 and 18 years old with at least one likely unauthorized parent. Hispanic ethnicity and lack of citizenship are as used as proxy for likely unauthorized status. Data from 2005-2011 ACS. 
Table 2: Immigration Enforcement and the Probability of Living below the Poverty Line

\begin{tabular}{|c|c|c|c|c|}
\hline & 1 & 2 & 3 & 4 \\
\hline Enforcement Index & $\begin{array}{c}0.045^{* * * *} \\
(0.008)\end{array}$ & $\begin{array}{c}0.019 * * * \\
(0.007)\end{array}$ & $\begin{array}{c}0.020 * * * \\
(0.005)\end{array}$ & $\begin{array}{c}0.021 * * \\
(0.010)\end{array}$ \\
\hline Single Headed HH & $\begin{array}{c}0.251 * * * \\
(0.005)\end{array}$ & $\begin{array}{c}0.246 * * * \\
(0.004)\end{array}$ & $\begin{array}{c}0.246 * * * \\
(0.004)\end{array}$ & $\begin{array}{c}0.246^{* * * *} \\
(0.004)\end{array}$ \\
\hline HH Head w/HS+ & $\begin{array}{c}-0.083^{* * * *} \\
(0.004)\end{array}$ & $\begin{array}{c}-0.084 * * * \\
(0.004)\end{array}$ & $\begin{array}{c}-0.084 * * * \\
(0.004)\end{array}$ & $\begin{array}{c}-0.084 * * * \\
(0.004)\end{array}$ \\
\hline HH Head Does Not Speak English & $\begin{array}{c}0.116^{* * * *} \\
(0.004)\end{array}$ & $\begin{array}{c}0.111 * * * \\
(0.004)\end{array}$ & $\begin{array}{c}0.111 * * * \\
(0.004)\end{array}$ & $\begin{array}{c}0.111 * * * \\
(0.004)\end{array}$ \\
\hline Years in the U.S. for the HH Head & $\begin{array}{c}-0.003 * * * \\
(0.000)\end{array}$ & $\begin{array}{c}-0.003 * * * \\
(0.000)\end{array}$ & $\begin{array}{c}-0.003 * * * \\
(0.000)\end{array}$ & $\begin{array}{c}-0.003 * * * \\
(0.000)\end{array}$ \\
\hline Employed HH Head & $\begin{array}{c}-0.219 * * * \\
(0.004)\end{array}$ & $\begin{array}{c}-0.210 * * * \\
(0.004)\end{array}$ & $\begin{array}{c}-0.210 * * * \\
(0.004)\end{array}$ & $\begin{array}{c}-0.210 * * * \\
(0.004)\end{array}$ \\
\hline Age of the HH Head & $\begin{array}{c}-0.005^{* * * *} \\
(0.000)\end{array}$ & $\begin{array}{c}-0.005 * * * \\
(0.000)\end{array}$ & $\begin{array}{c}-0.005^{* * *} * \\
(0.000)\end{array}$ & $\begin{array}{c}-0.005 * * * \\
(0.000)\end{array}$ \\
\hline No. of Kids in the $\mathrm{HH}$ & $\begin{array}{c}0.070 * * * \\
(0.002)\end{array}$ & $\begin{array}{c}0.069 * * * \\
(0.002)\end{array}$ & $\begin{array}{c}0.069 * * * \\
(0.002)\end{array}$ & $\begin{array}{c}0.069 * * * \\
(0.002)\end{array}$ \\
\hline Share Voting Republican in State & & & $\begin{array}{c}-0.184 * \\
(0.094)\end{array}$ & $\begin{array}{l}-0.064 \\
(0.118)\end{array}$ \\
\hline Unemployment Rate in CONSPUMA & & & $\begin{array}{c}0.751 * * * \\
(0.186)\end{array}$ & $\begin{array}{c}0.061 \\
(0.207)\end{array}$ \\
\hline $\begin{array}{l}\text { CONSPUMA FE } \\
\text { Year FE } \\
\text { CONSPUMA-specific Time Trend }\end{array}$ & & $\begin{array}{l}\text { Yes } \\
\text { Yes }\end{array}$ & $\begin{array}{l}\text { Yes } \\
\text { Yes }\end{array}$ & $\begin{array}{l}\text { Yes } \\
\text { Yes } \\
\text { Yes }\end{array}$ \\
\hline $\begin{array}{l}\text { Observations } \\
\text { R-squared }\end{array}$ & $\begin{array}{c}150,141 \\
0.186\end{array}$ & $\begin{array}{c}150,141 \\
0.209\end{array}$ & $\begin{array}{c}150,141 \\
0.209\end{array}$ & $\begin{array}{c}150,141 \\
0.214\end{array}$ \\
\hline Dependent Variable Mean & \multicolumn{4}{|c|}{0.32} \\
\hline
\end{tabular}

Notes: Table 2 reports the results from estimating equation (3) on a sample of mixed-status households with a likely undocumented parent and at least a U.S. born child between 0 and 18 years of age. Hispanic ethnicity and lack of citizenship are as used as proxy for likely undocumented status. Specification 1 includes only family characteristics. Specification 2 includes area and time fixed effects. Specification 3 adds aggregate State/CONSPUMA controls, and Specification 4 further adds the CONSPUMA-specific time trend. Robust standard errors are shown in parentheses. Standards errors are clustered at the CONSPUMA level. $* * * p<0.01$, $* * \mathrm{p}<0.05, * \mathrm{p}<0.1$. 
Table 3: Immigration Enforcement and the Probability of Living below the Poverty Line Families with Hispanic Naturalized Parents

\begin{tabular}{|c|c|c|c|c|}
\hline & 1 & 2 & 3 & 4 \\
\hline Enforcement Index & $\begin{array}{l}0.010 * \\
(0.006)\end{array}$ & $\begin{array}{l}-0.001 \\
(0.007)\end{array}$ & $\begin{array}{c}0.001 \\
(0.007)\end{array}$ & $\begin{array}{l}-0.014 \\
(0.013)\end{array}$ \\
\hline Single Headed HH & $\begin{array}{c}0.183 * * * \\
(0.007)\end{array}$ & $\begin{array}{c}0.173 * * * \\
(0.006)\end{array}$ & $\begin{array}{c}0.173 * * * \\
(0.006)\end{array}$ & $\begin{array}{c}0.173 * * * \\
(0.006)\end{array}$ \\
\hline HH Head w/HS+ & $\begin{array}{c}-0.061 * * * \\
(0.005)\end{array}$ & $\begin{array}{c}-0.064 * * * \\
(0.006)\end{array}$ & $\begin{array}{c}-0.064 * * * \\
(0.005)\end{array}$ & $\begin{array}{c}-0.064 * * * \\
(0.006)\end{array}$ \\
\hline HH Head Does Not Speak English & $\begin{array}{c}0.085 * * * \\
(0.007)\end{array}$ & $\begin{array}{c}0.079 * * * \\
(0.006)\end{array}$ & $\begin{array}{c}0.079 * * * \\
(0.006)\end{array}$ & $\begin{array}{c}0.078 * * * \\
(0.006)\end{array}$ \\
\hline Years in the U.S. for the HH Head & $\begin{array}{c}-0.002 * * * \\
(0.000)\end{array}$ & $\begin{array}{c}-0.001 * * * \\
(0.000)\end{array}$ & $\begin{array}{c}-0.001 * * * \\
(0.000)\end{array}$ & $\begin{array}{c}-0.001 * * * \\
(0.000)\end{array}$ \\
\hline Employed HH Head & $\begin{array}{c}-0.231 * * * \\
(0.009)\end{array}$ & $\begin{array}{c}-0.225 * * * \\
(0.008)\end{array}$ & $\begin{array}{c}-0.226 * * * \\
(0.008)\end{array}$ & $\begin{array}{c}-0.225 * * * \\
(0.008)\end{array}$ \\
\hline Age of the HH Head & $\begin{array}{c}-0.003 * * * \\
(0.000)\end{array}$ & $\begin{array}{c}-0.003 * * * \\
(0.000)\end{array}$ & $\begin{array}{c}-0.003 * * * \\
(0.000)\end{array}$ & $\begin{array}{c}-0.003 * * * \\
(0.000)\end{array}$ \\
\hline No. of Kids in the $\mathrm{HH}$ & & $\begin{array}{c}0.037 * * * \\
(0.003)\end{array}$ & $\begin{array}{c}0.037 * * * \\
(0.003)\end{array}$ & $\begin{array}{c}0.037 * * * \\
(0.003)\end{array}$ \\
\hline Share Voting Republican in State & & & $\begin{array}{l}-0.040 \\
(0.124)\end{array}$ & $\begin{array}{c}0.105 \\
(0.153)\end{array}$ \\
\hline Unemployment Rate in CONSPUMA & & & $\begin{array}{c}0.049 \\
(0.031)\end{array}$ & $\begin{array}{l}0.0455 \\
(0.313)\end{array}$ \\
\hline $\begin{array}{l}\text { CONSPUMA FE } \\
\text { Year FE } \\
\text { CONSPUMA-specific Time Trend }\end{array}$ & & $\begin{array}{l}\text { Yes } \\
\text { Yes }\end{array}$ & $\begin{array}{l}\text { Yes } \\
\text { Yes }\end{array}$ & $\begin{array}{l}\text { Yes } \\
\text { Yes } \\
\text { Yes }\end{array}$ \\
\hline $\begin{array}{l}\text { Observations } \\
\text { R-squared }\end{array}$ & $\begin{array}{c}48,250 \\
0.186\end{array}$ & $\begin{array}{c}48,250 \\
0.209\end{array}$ & $\begin{array}{c}48,250 \\
0.209\end{array}$ & $\begin{array}{c}48,250 \\
0.214\end{array}$ \\
\hline Dependent Variable Mean: & \multicolumn{4}{|c|}{0.14} \\
\hline
\end{tabular}

Notes: Table 3 reports the results from estimating equation (3) on a sample of mixed-status households with at least a U.S. born child between 0 and 18 years of age and Hispanic parents as in Table 2, but with both parents naturalized. Specification 1 includes only family characteristics. Specification 2 includes area and time fixed effects. Specification 3 adds aggregate State/CONSPUMA controls, and Specification 4 further adds the CONSPUMA-specific time trend. Robust standard errors are shown in parentheses. Standards errors are clustered at the CONSPUMA level. $* * * p<0.01,{ }^{*} \mathrm{p}<0.05,{ }^{*} \mathrm{p}<0.1$. 
Table 4: Immigration Enforcement and the Probability of Living below the Poverty Line Families with Hispanic Native Parents

\begin{tabular}{|c|c|c|c|c|}
\hline & 1 & 2 & 3 & 4 \\
\hline Enforcement Index & $\begin{array}{c}0.002 \\
(0.005)\end{array}$ & $\begin{array}{c}0.000 \\
(0.003)\end{array}$ & $\begin{array}{l}-0.000 \\
(0.003)\end{array}$ & $\begin{array}{l}-0.006 \\
(0.006)\end{array}$ \\
\hline Single Headed HH & $\begin{array}{c}0.245^{* * *} \\
(0.005)\end{array}$ & $\begin{array}{c}0.242 * * * \\
(0.005)\end{array}$ & $\begin{array}{c}0.242 * * * \\
(0.005)\end{array}$ & $\begin{array}{c}0.242 * * * \\
(0.005)\end{array}$ \\
\hline HH Head w/HS+ & $\begin{array}{c}-0.092 * * * \\
(0.004)\end{array}$ & $\begin{array}{c}-0.089 * * * \\
(0.003)\end{array}$ & $\begin{array}{c}-0.089 * * * \\
(0.003)\end{array}$ & $\begin{array}{c}-0.089 * * * \\
(0.003)\end{array}$ \\
\hline HH Head Does Not Speak English & $\begin{array}{c}0.119 * * * \\
(0.014)\end{array}$ & $\begin{array}{c}0.112 * * * \\
(0.013)\end{array}$ & $\begin{array}{c}0.112 * * * \\
(0.013)\end{array}$ & $\begin{array}{c}0.111 * * * \\
(0.013)\end{array}$ \\
\hline Years in the U.S. for the HH Head & $\begin{array}{l}-0.000 \\
(0.000)\end{array}$ & $\begin{array}{c}0.000 * * \\
(0.000)\end{array}$ & $\begin{array}{c}0.000 * * \\
(0.000)\end{array}$ & $\begin{array}{c}0.000 * * \\
(0.000)\end{array}$ \\
\hline Employed HH Head & $\begin{array}{c}-0.296 * * * \\
(0.004)\end{array}$ & $\begin{array}{c}-0.293 * * * \\
(0.004)\end{array}$ & $\begin{array}{c}-0.293 * * * \\
(0.004)\end{array}$ & $\begin{array}{c}-0.293 * * * \\
(0.004)\end{array}$ \\
\hline Age of the HH Head & $\begin{array}{c}-0.006 * * * \\
(0.000)\end{array}$ & $\begin{array}{c}-0.006^{* * *} * \\
(0.000)\end{array}$ & $\begin{array}{c}-0.006^{* * *} \\
(0.000)\end{array}$ & $\begin{array}{c}-0.006 * * * \\
(0.000)\end{array}$ \\
\hline No. of Kids in the $\mathrm{HH}$ & & $\begin{array}{c}0.049 * * * \\
(0.001)\end{array}$ & $\begin{array}{c}0.049 * * * \\
(0.001)\end{array}$ & $\begin{array}{c}0.049 * * * \\
(0.002)\end{array}$ \\
\hline Share Voting Republican in State & & & $\begin{array}{l}-0.065 \\
(0.049)\end{array}$ & $\begin{array}{l}-0.038 \\
(0.068)\end{array}$ \\
\hline Unemployment Rate in CONSPUMA & & & $\begin{array}{c}0.066^{* * *} \\
(0.018)\end{array}$ & $\begin{array}{c}0.036 \\
(0.031)\end{array}$ \\
\hline CONSPUMA FE & & Yes & Yes & Yes \\
\hline Year FE & & Yes & Yes & Yes \\
\hline CONSPUMA-specific Time Trend & & & & Yes \\
\hline Observations & 161,690 & 161,690 & 161,690 & 161,690 \\
\hline R-squared & 0.300 & 0.314 & 0.314 & 0.318 \\
\hline Dependent Variable Mean: & \multicolumn{4}{|c|}{0.18} \\
\hline
\end{tabular}

Notes: Table 4 reports the results from estimating equation (3) on a sample of households with at least one U.S. born child between 0 and 18 years of age and Hispanic parents as in Table 2, but with both parents being native. Specification 1 includes only family characteristics. Specification 2 includes area and time fixed effects. Specification 3 adds aggregate State/CONSPUMA controls, and Specification 4 further adds the CONSPUMA-specific time trend. Robust standard errors are shown in parentheses. Standards errors are clustered at the CONSPUMA level. ***p<0.01, $* * \mathrm{p}<0.05, * \mathrm{p}<0.1$. 
Table 5: Immigration Enforcement and the Probability of Living below the Poverty Line Robustness Check Using Alternative Definitions of Poverty

\begin{tabular}{lccc}
\hline & 1 & 2 & Households with at least \\
one LU parent & $\begin{array}{c}\text { Households of } \\
\text { Hispanic Naturalized } \\
\text { Parents }\end{array}$ & $\begin{array}{c}\text { Households of } \\
\text { Hispanic Native } \\
\text { Parents }\end{array}$ \\
\hline Panel A: HH Income is No more than 1.5 Times the Poverty Threshold & \\
\hline Enforcement Index & $0.021^{* *}$ & -0.017 & 0.000 \\
Observations & $(0.009)$ & $(0.012)$ & $(0.005)$ \\
R-squared & 150,141 & 48,250 & 185,335 \\
Dependent Variable Mean & 0.251 & 0.251 & 0.326 \\
\hline Panel B: Log (Real HH Income) & 0.58 & 0.28 & 0.29 \\
\hline Enforcement Index & & & -0.006 \\
& $-0.029^{* *}$ & 0.023 & $(0.011)$ \\
Observations & $(0.013)$ & $(0.022)$ & 183,128 \\
R-squared & 147,049 & 48,628 & 0.451 \\
Dependent Variable Mean & 0.277 & 0.37 & 10.50 \\
\hline Panel C: Food Stamp Receipt & 10.09 & 10.53 & \\
\hline Enforcement Index & & & 0.002 \\
Observations & $0.023^{* *}$ & -0.018 & $(0.007)$ \\
R-squared & $(0.009)$ & $(0.012)$ & 185,335 \\
Dependent Variable Mean & 150,141 & 48,250 & 0.255 \\
CONSPUMA FE & 0.105 & 0.251 & 0.18 \\
Year FE & 0.22 & 0.13 & Yes \\
CONSPUMA-specific Trends & Yes & Yes & Yes \\
\hline
\end{tabular}

Notes: Table 5 reports the results from estimating equation (3) on a sample of mixed-status households with at least a U.S. born child between 0 and 18 years of age and Hispanic parents as in Table 2. The sample in Column 1 is households with at least one likely unauthorized parent. The sample in Column 2 is households where both parents are naturalized. The sample in Column 3 is households where both parents are native. We use three alternative dependent variables indicative of economic need. In Panel A, the dependent variable is 'near poverty' and it equals 1 when the household's income is below 1.5 times the poverty threshold. In Panel B, we use the logarithm of total household income in constant dollars. In Panel $\mathrm{C}$, the dependent variable is a dummy equal to 1 if the family received food stamps at any time in the last 12 months. In all instances, our sample is composed of households with at least one U.S. born child between 0 and 18 years of age with an undocumented parent. Robust standard errors in parentheses. ${ }^{* * *} \mathrm{p}<0.01,{ }^{*} \mathrm{p}<0.05,{ }^{*} \mathrm{p}<0.1$. Standards errors are clustered at the CONSPUMA level. 
Table 6A: Immigration Enforcement and the Probability of Living below the Poverty Line Robustness Check Using Alternative Definitions of Likely Unauthorized

\begin{tabular}{|c|c|c|c|c|}
\hline \multirow{2}{*}{\multicolumn{5}{|c|}{$\begin{array}{lcc}1 & 2 & 3 \\
\text { Panel A: Likely Unauthorized Parent with More than } 5 \text { Years of U.S. Residency }\end{array}$}} \\
\hline & & & & \\
\hline Enforcement Index & $\begin{array}{c}0.050 * * * \\
(0.009)\end{array}$ & $\begin{array}{c}0.022 * * * \\
(0.006)\end{array}$ & $\begin{array}{c}0.023 * * * \\
(0.005)\end{array}$ & $\begin{array}{c}0.028 * * \\
(0.012)\end{array}$ \\
\hline Observations & 118,529 & 118,529 & 118,529 & 118,529 \\
\hline R-squared & 0.182 & 0.206 & 0.206 & 0.212 \\
\hline Dependent Variable Mean & \multicolumn{4}{|c|}{0.30} \\
\hline \multicolumn{5}{|c|}{ Panel B: Likely Unauthorized Parent who Lacks HS Diploma } \\
\hline Enforcement Index & $\begin{array}{c}0.054 * * * \\
(0.011)\end{array}$ & $\begin{array}{c}0.025 * * * \\
(0.007)\end{array}$ & $\begin{array}{c}0.025 * * * \\
(0.007)\end{array}$ & $\begin{array}{c}0.029 * * \\
(0.013)\end{array}$ \\
\hline Observations & 75,091 & 75,091 & 75,091 & 75,091 \\
\hline R-squared & 0.158 & 0.189 & 0.189 & 0.198 \\
\hline Dependent Variable Mean & \multicolumn{4}{|c|}{0.38} \\
\hline \multicolumn{5}{|c|}{ Panel C: Likely Unauthorized Parent of Less than 45 Years of Age } \\
\hline Enforcement Index & $\begin{array}{c}0.045^{* * * *} \\
(0.008)\end{array}$ & $\begin{array}{c}0.020 * * * \\
(0.007)\end{array}$ & $\begin{array}{c}0.021 * * * \\
(0.006)\end{array}$ & $\begin{array}{c}0.021 * * \\
(0.011)\end{array}$ \\
\hline Observations & 130,275 & 130,275 & 130,275 & 130,275 \\
\hline R-squared & 0.193 & 0.217 & 0.217 & 0.221 \\
\hline Dependent Variable Mean & \multicolumn{4}{|c|}{0.32} \\
\hline CONSPUMA FE & & Yes & Yes & Yes \\
\hline Year FE & & Yes & Yes & Yes \\
\hline CONSPUMA-specific Time Trend & & & & Yes \\
\hline
\end{tabular}

Notes: Table 6 reports the results from estimating equation (3) on a sample of mixed-status households with at least one U.S. born child between 0 and 18 years of age, and with a likely undocumented parent. Panel A uses a sample where likely undocumented parent is defined as Hispanic ethnicity and lack of citizenship as in our main analysis, with the additional restriction of having more than 5 years of residency status. Panel B uses a sample where likely undocumented parent is defined as Hispanic ethnicity and lack of citizenship as in our main analysis, with the additional restriction that the level of education is lower than high school diploma. Panel $\mathrm{C}$ uses a sample where likely undocumented parent is defined as Hispanic ethnicity and lack of citizenship as in our main analysis, with the additional restriction of being older than 45 years old. Specification 1 includes only family characteristics. Specification 2 includes area and time fixed effects. Specification 3 adds aggregate CONSPUMA-time controls, and Specification 4 further adds the CONSPUMA-specific time trend. Robust standard errors are shown in parentheses. Standards errors are clustered at the CONSPUMA level. ***p<0.01, $* * \mathrm{p}<0.05,{ }^{*} \mathrm{p}<0.1$. 
Table 6B: Immigration Enforcement and the Probability of Living below the Poverty Line Households with Hispanic Naturalized and Hispanic Native Parents

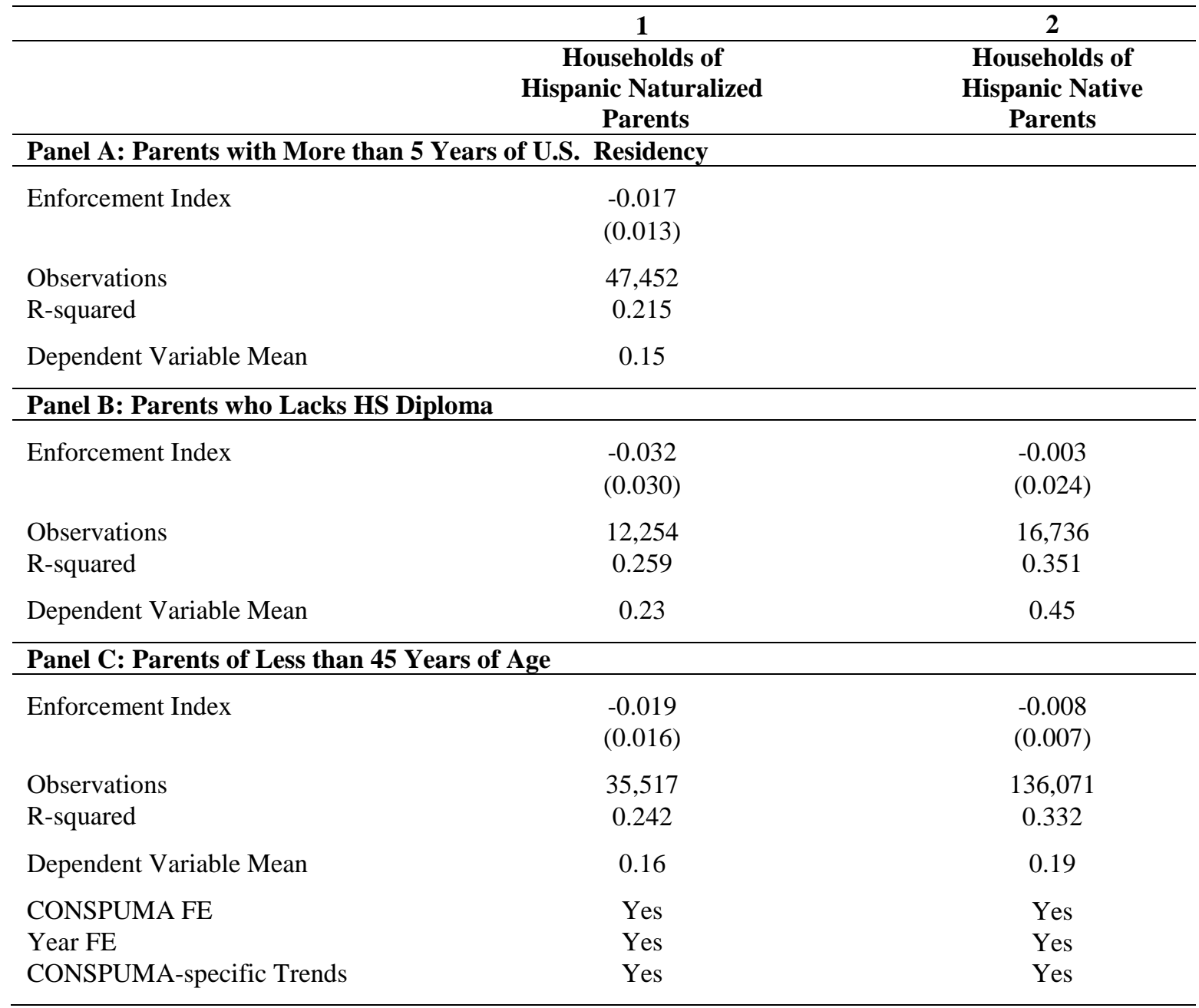

Notes: Table 6B reports the estimates from equation (3) using the specification in Column 4 in Table 6A using different samples. The sample in Column 1 is households where both parents are naturalized. The sample in Column 2 is households where both parents are native. Robust standard errors in parentheses. Standards errors are clustered at the CONSPUMA level. ***p $<0.01, * * p<0.05,{ }^{*} \mathrm{p}<0.1$. 
Table 7: Immigration Enforcement and the Probability of Living below the Poverty Line Robustness Checks Using Alternative Samples

\begin{tabular}{|c|c|c|c|c|}
\hline & $\mathbf{1}$ & 2 & 3 & 4 \\
\hline \multicolumn{5}{|l|}{ Panel A: Excluding 2009} \\
\hline Enforcement Index & $\begin{array}{c}0.055 * * * \\
(0.010)\end{array}$ & $\begin{array}{c}0.023 * * * \\
(0.006)\end{array}$ & $\begin{array}{c}0.023 * * * \\
(0.005)\end{array}$ & $\begin{array}{c}0.022 * * \\
(0.011)\end{array}$ \\
\hline $\begin{array}{l}\text { Observations } \\
\text { R-squared }\end{array}$ & $\begin{array}{c}113,656 \\
0.185\end{array}$ & $\begin{array}{c}113,656 \\
0.211\end{array}$ & $\begin{array}{c}113,549 \\
0.211\end{array}$ & $\begin{array}{c}113,549 \\
0.215\end{array}$ \\
\hline Dependent Variable Mean & \multicolumn{4}{|c|}{0.31} \\
\hline \multicolumn{5}{|c|}{ Panel B: Excluding Maricopa County } \\
\hline Enforcement Index & $\begin{array}{c}0.062 * * * \\
(0.008)\end{array}$ & $\begin{array}{c}0.014 * * \\
(0.007)\end{array}$ & $\begin{array}{c}0.016 * * \\
(0.007)\end{array}$ & $\begin{array}{l}0.015^{*} \\
(0.008)\end{array}$ \\
\hline Observations & 130,177 & 130,177 & 130,053 & 130,053 \\
\hline R-squared & 0.185 & 0.210 & 0.210 & 0.213 \\
\hline Dependent Variable Mean & \multicolumn{4}{|c|}{0.32} \\
\hline \multicolumn{5}{|c|}{ Panel C: Including Households all Mixed Status HHs, Regardless of the Children's Citizenship } \\
\hline Enforcement Index & $\begin{array}{c}0.049 * * * \\
(0.009)\end{array}$ & $\begin{array}{c}0.020 * * * \\
(0.006)\end{array}$ & $\begin{array}{c}0.020 * * * \\
(0.005)\end{array}$ & $\begin{array}{c}0.017 \text { ** } \\
(0.007)\end{array}$ \\
\hline Observations & 151,487 & 151,487 & 151,344 & 151,344 \\
\hline R-squared & 0.178 & 0.202 & 0.202 & 0.205 \\
\hline Dependent Variable Mean & \multicolumn{4}{|c|}{0.31} \\
\hline CONSPUMA FE & & Yes & Yes & Yes \\
\hline Year FE & & Yes & Yes & Yes \\
\hline CONSPUMA-specific Time Trend & & & & Yes \\
\hline
\end{tabular}

Notes: Table 7 reports the estimates from equation (3). Samples in Panels A and B: Households with at least one U.S. born child between 0 and 18 years of age with a likely undocumented parent. The sample in Panel C is households with at least one child between 0 and 18 years of age with a likely undocumented parent, including households where all children are US-citizen. Hispanic ethnicity and lack of citizenship are as used as proxy for likely undocumented status. Specification 1 includes only family characteristics. Specification 2 includes area and time fixed effects. Specification 3 adds aggregate State/CONSPUMA controls, and Specification 4 further adds the CONSPUMA-specific time trend. Robust standard errors are shown in parentheses. Standards errors are clustered at the CONSPUMA level. $* * * \mathrm{p}<0.01, * * \mathrm{p}<0.05, * \mathrm{p}<0.1$. 
Table 8A: Immigration Enforcement and the Probability of Living below the Poverty Line Identification Check for Pre-Existing Parallel Trends

\begin{tabular}{lcccc}
\hline & $\mathbf{1}$ & $\mathbf{2}$ & $\mathbf{3}$ & $\mathbf{4}$ \\
\hline Elapsed time & & & & \\
-4 & -0.009 & 0.007 & 0.004 & 0.003 \\
& $(0.009)$ & $(0.006)$ & $(0.005)$ & $(0.006)$ \\
-3 & -0.002 & 0.008 & 0.005 & 0.006 \\
& $(0.009)$ & $(0.006)$ & $(0.006)$ & $(0.006)$ \\
-2 & 0.002 & -0.000 & 0.001 & 0.002 \\
& $(0.007)$ & $(0.006)$ & $(0.005)$ & $(0.006)$ \\
-1 & $0.014 * *$ & 0.006 & 0.009 & 0.008 \\
& $(0.006)$ & $(0.006)$ & $(0.006)$ & $(0.006)$ \\
Enforcement Index & $0.046^{* * *}$ & $0.020 * * *$ & $0.022 * * *$ & $0.024 * *$ \\
& $(0.008)$ & $(0.007)$ & $(0.006)$ & $(0.011)$ \\
CONSPUMA FE & & Yes & Yes & Yes \\
Year FE & & Yes & Yes & Yes \\
CONSPUMA-specific Time Trend & & & & Yes \\
Observations & 150,141 & 150,141 & 150,141 & 150,141 \\
R-squared & 0.187 & 0.209 & 0.209 & 0.215 \\
\hline
\end{tabular}

Notes: Table $8 \mathrm{~A}$ reports the results from estimating equation (4a) using households with at least one U.S. born child between 0 and 18 years of age with a likely undocumented parent. Hispanic ethnicity and lack of citizenship are used as proxy for likely undocumented status. Specification 1 includes only family characteristics. Specification 2 includes area and time fixed effects. Specification 3 adds aggregate State/CONSPUMA controls, and Specification 4 further adds the CONSPUMA-specific time trend. Robust standard errors are shown in parentheses. Standards errors are clustered at the CONSPUMA level. $* * * \mathrm{p}<0.01$, $* * \mathrm{p}<0.05, * \mathrm{p}<0.1$. 
Table 8B: Immigration Enforcement and the Probability of Living below the Poverty Line Identification Check for Pre-Existing Parallel Trends \#2

\begin{tabular}{|c|c|c|c|c|}
\hline & 1 & 2 & 3 & 4 \\
\hline \multicolumn{5}{|l|}{ Elapsed time* LU parents } \\
\hline$-4 * \mathrm{LU}$ & $\begin{array}{c}0.008 \\
(0.011)\end{array}$ & $\begin{array}{c}0.000 \\
(0.011)\end{array}$ & $\begin{array}{l}-0.002 \\
(0.011)\end{array}$ & $\begin{array}{l}-0.002 \\
(0.011)\end{array}$ \\
\hline$-3 * \mathrm{LU}$ & $\begin{array}{c}0.014 \\
(0.010)\end{array}$ & $\begin{array}{c}0.012 \\
(0.009)\end{array}$ & $\begin{array}{c}0.011 \\
(0.009)\end{array}$ & $\begin{array}{c}0.011 \\
(0.009)\end{array}$ \\
\hline$-2 * \mathrm{LU}$ & $\begin{array}{c}0.013 \\
(0.008)\end{array}$ & $\begin{array}{c}0.006 \\
(0.008)\end{array}$ & $\begin{array}{c}0.005 \\
(0.008)\end{array}$ & $\begin{array}{c}0.004 \\
(0.008)\end{array}$ \\
\hline$-1 * \mathrm{LU}$ & $\begin{array}{c}0.011 \\
(0.008)\end{array}$ & $\begin{array}{c}0.004 \\
(0.008)\end{array}$ & $\begin{array}{c}0.003 \\
(0.008)\end{array}$ & $\begin{array}{c}0.003 \\
(0.008)\end{array}$ \\
\hline Enforcement Index*LU & $\begin{array}{c}0.047 * * * \\
(0.009)\end{array}$ & $\begin{array}{c}0.027 * * * \\
(0.004)\end{array}$ & $\begin{array}{c}0.028 * * * \\
(0.004)\end{array}$ & $\begin{array}{c}0.029 * * * \\
(0.004)\end{array}$ \\
\hline $\begin{array}{l}\text { CONSPUMA FE } \\
\text { Year FE } \\
\text { CONSPUMA-specific Time Trend }\end{array}$ & & $\begin{array}{l}\text { Yes } \\
\text { Yes }\end{array}$ & $\begin{array}{l}\text { Yes } \\
\text { Yes }\end{array}$ & $\begin{array}{l}\text { Yes } \\
\text { Yes } \\
\text { Yes }\end{array}$ \\
\hline $\begin{array}{l}\text { Observations } \\
\text { R-squared }\end{array}$ & $\begin{array}{c}198,393 \\
0.201\end{array}$ & $\begin{array}{c}198,393 \\
0.221\end{array}$ & $\begin{array}{c}198,393 \\
0.221\end{array}$ & $\begin{array}{c}198,393 \\
0.225\end{array}$ \\
\hline
\end{tabular}

Notes: Table $8 \mathrm{~B}$ reports the results from estimating equation (4b) using all households with at least one U.S. born child between 0 and 18 years of age. Specification 1 includes only family characteristics. Specification 2 includes area and time fixed effects. Specification 3 adds aggregate State/CONSPUMA controls, and Specification 4 further adds the CONSPUMA-specific time trend. Robust standard errors are shown in parentheses. Standards errors are clustered at the CONSPUMA level. $* * * p<0.01, * * p<0.05,{ }^{*} p<0.1$. 
Table 9: Immigration Enforcement and the Probability of Living below the Poverty Line Identification Check for Endogenous Immigration Enforcement Adoption by the MSA

\begin{tabular}{|c|c|c|c|c|}
\hline & 1 & 2 & 3 & 4 \\
\hline Share of HHs Living below the Poverty Line & $\begin{array}{c}11.008 \\
(42.112)\end{array}$ & $\begin{array}{c}-3.770 \\
(27.146)\end{array}$ & $\begin{array}{c}-44.772 \\
(54.269)\end{array}$ & $\begin{array}{c}-39.601 \\
(42.740)\end{array}$ \\
\hline Share of Single Headed HHs & & $\begin{array}{c}1.191 \\
(43.852)\end{array}$ & $\begin{array}{l}-19.499 \\
(28.369)\end{array}$ & $\begin{array}{l}-27.679 \\
(35.347)\end{array}$ \\
\hline Share of HH Heads with a HS Education or More & & $\begin{array}{c}37.219 \\
(66.843)\end{array}$ & $\begin{array}{c}25.073 \\
(35.953)\end{array}$ & $\begin{array}{c}12.619 \\
(25.638)\end{array}$ \\
\hline Share of HH Heads without a HS Diploma & & $\begin{array}{c}6.257 \\
(30.791)\end{array}$ & $\begin{array}{c}21.536 \\
(22.799)\end{array}$ & $\begin{array}{c}37.538 \\
(41.942)\end{array}$ \\
\hline Share of non-English proficient $\mathrm{HH}$ heads & & $\begin{array}{c}29.352 \\
(52.684)\end{array}$ & $\begin{array}{c}-4.494 \\
(25.492)\end{array}$ & $\begin{array}{l}-20.236 \\
(44.669)\end{array}$ \\
\hline Average Number of Years in the U.S. & & $\begin{array}{l}-1.476 \\
(2.088)\end{array}$ & $\begin{array}{c}1.417 \\
(2.099)\end{array}$ & $\begin{array}{c}0.417 \\
(1.191)\end{array}$ \\
\hline Share of Working HH Heads & & $\begin{array}{l}-31.057 \\
(51.467)\end{array}$ & $\begin{array}{c}28.959 \\
(33.506)\end{array}$ & $\begin{array}{c}25.438 \\
(29.659)\end{array}$ \\
\hline Average Age of HH Head & & $\begin{array}{l}-0.082 \\
(2.358)\end{array}$ & $\begin{array}{l}-3.418 \\
(4.194)\end{array}$ & $\begin{array}{l}-1.250 \\
(2.636)\end{array}$ \\
\hline Average number of kids per $\mathrm{HH}$ & & $\begin{array}{c}9.129 \\
(20.647)\end{array}$ & $\begin{array}{c}-5.089 \\
(21.922)\end{array}$ & $\begin{array}{l}-11.278 \\
(21.094)\end{array}$ \\
\hline Average Unemployment Rate & & & & $\begin{array}{l}-767.924 \\
(852.855)\end{array}$ \\
\hline Share of Low-skilled in Agriculture & & & & $\begin{array}{l}-20.172 \\
(64.006)\end{array}$ \\
\hline Share of Low-skilled in Services & & & & $\begin{array}{c}649.001 \\
(752.896)\end{array}$ \\
\hline Share of Low-skilled in Manufacturing & & & & $\begin{array}{l}-178.033 \\
(189.593)\end{array}$ \\
\hline Share of Low-skilled in Construction & & & & $\begin{array}{l}-365.951 \\
(374.871)\end{array}$ \\
\hline Share Voting Republican in State & & & & $\begin{array}{c}58.742 \\
(149.643)\end{array}$ \\
\hline Constant & $\begin{array}{c}1,981.402 * * * \\
(19.085)\end{array}$ & $\begin{array}{c}1,988.301 * * * \\
(61.081)\end{array}$ & $\begin{array}{c}2,072.350 * * * \\
\quad(122.300)\end{array}$ & $\begin{array}{c}2,000.851 * * * \\
\quad(161.744)\end{array}$ \\
\hline MSA FE & No & No & Yes & Yes \\
\hline Observations & 478 & 478 & 478 & 478 \\
\hline R-squared & 0.002 & 0.003 & 0.593 & 0.609 \\
\hline
\end{tabular}

Notes: Table 9 reports estimates from Eq. (5). All control variables are measured at the CONSPUMA level, with the exception of the share voting republican, which is measured at the state level. Robust standard errors are in parentheses and clustered at the Metropolitan Statistical Area (MSA) level. ***p $<0.01, * * \mathrm{p}<0.05, * \mathrm{p}<0.1$. 
Table 10: Immigration Enforcement and the Probability of Living below the Poverty Line Identification Check for Endogenous Residential Location of Migrants \#1

\begin{tabular}{|c|c|c|c|c|}
\hline & 1 & 2 & 3 & 4 \\
\hline Enforcement Index & $\begin{array}{c}0.052 * * * \\
(0.012)\end{array}$ & $\begin{array}{c}0.026 * * * \\
(0.010)\end{array}$ & $\begin{array}{c}0.024 * * * \\
(0.009)\end{array}$ & $\begin{array}{c}0.101 * * * \\
(0.020)\end{array}$ \\
\hline Single Headed HH & $\begin{array}{c}0.251 * * * \\
(0.005)\end{array}$ & $\begin{array}{c}0.246 * * * \\
(0.004)\end{array}$ & $\begin{array}{c}0.246 * * * \\
(0.004)\end{array}$ & $\begin{array}{c}0.246 * * * \\
(0.004)\end{array}$ \\
\hline HH Head w/HS+ & $\begin{array}{c}-0.083 * * * \\
(0.004)\end{array}$ & $\begin{array}{c}-0.084 * * * \\
(0.004)\end{array}$ & $\begin{array}{c}-0.084 * * * \\
(0.004)\end{array}$ & $\begin{array}{c}-0.084 * * * \\
(0.004)\end{array}$ \\
\hline HH Head Does Not Speak English & $\begin{array}{c}0.116 * * * \\
(0.004)\end{array}$ & $\begin{array}{c}0.111 * * * \\
(0.004)\end{array}$ & $\begin{array}{c}0.111 * * * \\
(0.004)\end{array}$ & $\begin{array}{c}0.111 * * * \\
(0.004)\end{array}$ \\
\hline Years in the U.S. for the HH Head & $\begin{array}{c}-0.003 * * * \\
(0.000)\end{array}$ & $\begin{array}{c}-0.003 * * * \\
(0.000)\end{array}$ & $\begin{array}{c}-0.003 * * * \\
(0.000)\end{array}$ & $\begin{array}{c}-0.003 * * * \\
(0.000)\end{array}$ \\
\hline Employed HH Head & $\begin{array}{c}-0.219 * * * \\
(0.004)\end{array}$ & $\begin{array}{c}-0.210 * * * \\
(0.004)\end{array}$ & $\begin{array}{c}-0.210 * * * \\
(0.004)\end{array}$ & $\begin{array}{c}-0.210 * * * \\
(0.004)\end{array}$ \\
\hline Age of the HH Head & $\begin{array}{c}-0.005^{* * * *} \\
(0.000)\end{array}$ & $\begin{array}{c}-0.005^{* * *} * \\
(0.000)\end{array}$ & $\begin{array}{c}-0.005^{* * * *} \\
(0.000)\end{array}$ & $\begin{array}{c}-0.005 * * * \\
(0.000)\end{array}$ \\
\hline No. of Kids in the HH & $\begin{array}{c}0.070 * * * \\
(0.002)\end{array}$ & $\begin{array}{c}0.069 * * * \\
(0.002)\end{array}$ & $\begin{array}{c}0.069 * * * \\
(0.002)\end{array}$ & $\begin{array}{c}0.069 * * * \\
(0.002)\end{array}$ \\
\hline Share Voting Republican in State & & & $\begin{array}{l}-0.106 \\
(0.085)\end{array}$ & $\begin{array}{l}-0.102 \\
(0.130)\end{array}$ \\
\hline Unemployment Rate in CONSPUMA & & & $\begin{array}{c}0.752 * * * \\
(0.186)\end{array}$ & $\begin{array}{c}0.075 \\
(0.218)\end{array}$ \\
\hline CONSPUMA FE & & Yes & Yes & Yes \\
\hline Year FE & & Yes & Yes & Yes \\
\hline CONSPUMA-specific Time Trend & & & & Yes \\
\hline $\begin{array}{l}\text { Observations } \\
\text { R-squared }\end{array}$ & $\begin{array}{c}150,141 \\
0.186\end{array}$ & $\begin{array}{c}150,141 \\
0.209\end{array}$ & $\begin{array}{c}150,141 \\
0.209\end{array}$ & $\begin{array}{c}150,141 \\
0.214\end{array}$ \\
\hline First Stage Results & & & & \\
\hline IV & $\begin{array}{c}3.405 * * * \\
(0.814)\end{array}$ & $\begin{array}{c}2.642 * * * \\
(0.659)\end{array}$ & $\begin{array}{c}2.733 * * * \\
(0.628)\end{array}$ & $\begin{array}{c}1.481 * * * \\
(0.276)\end{array}$ \\
\hline $\begin{array}{l}\text { R-squared } \\
\text { F-statistic }\end{array}$ & $\begin{array}{l}0.436 \\
5.165\end{array}$ & $\begin{array}{l}0.734 \\
34.19\end{array}$ & $\begin{array}{l}0.746 \\
30.25\end{array}$ & $\begin{array}{l}0.920 \\
40.36\end{array}$ \\
\hline Mean Dependent variable & \multicolumn{4}{|c|}{0.32} \\
\hline
\end{tabular}

Notes: Table 10 reports the results from estimating equation (3) using the instrument in equation (6) to address the nonrandom location of immigrants with respect to immigration enforcement. Our sample is households with at least one U.S. born child between 0 and 18 years of age with a likely undocumented parent. Hispanic ethnicity and lack of citizenship are as used as proxy for likely undocumented status. Specification 1 includes only family characteristics. Specification 2 includes area and time fixed effects. Specification 3 adds aggregate State/CONSPUMA controls, and Specification 4 further adds the CONSPUMA-specific time trend. Robust standard errors are shown in parentheses. Standards errors are clustered at the CONSPUMA level. $* * * \mathrm{p}<0.01, * * \mathrm{p}<0.05, * \mathrm{p}<0.1$. 
Table 11: Immigration Enforcement and the Probability of Living below the Poverty Line Policy Channels

\begin{tabular}{|c|c|c|c|c|}
\hline & 1 & 2 & 3 & 4 \\
\hline \multicolumn{5}{|c|}{ Panel A: By Type of Enforcement Measure } \\
\hline Police-based enforcement & $\begin{array}{c}0.046^{* * * *} \\
(0.014)\end{array}$ & $\begin{array}{l}0.015^{*} \\
(0.008)\end{array}$ & $\begin{array}{c}0.018 * * \\
(0.007)\end{array}$ & $\begin{array}{c}0.022 * * * \\
(0.009)\end{array}$ \\
\hline Employment-based enforcement & $\begin{array}{c}0.045 * * * \\
(0.013)\end{array}$ & $\begin{array}{c}0.025 * * \\
(0.012)\end{array}$ & $\begin{array}{c}0.023 * * \\
(0.011)\end{array}$ & $\begin{array}{c}0.019 \\
(0.024)\end{array}$ \\
\hline $\begin{array}{l}\text { Observations } \\
\text { R-squared }\end{array}$ & $\begin{array}{c}150,141 \\
0.187\end{array}$ & $\begin{array}{c}150,141 \\
0.209\end{array}$ & $\begin{array}{c}150,141 \\
0.209\end{array}$ & $\begin{array}{c}150,141 \\
0.214\end{array}$ \\
\hline \multicolumn{5}{|c|}{ Panel B: By Geographic Scope of the Enforcement Measure } \\
\hline Local-level Enforcement & $\begin{array}{c}0.081 * * * \\
(0.016)\end{array}$ & $\begin{array}{l}0.024 * \\
(0.014)\end{array}$ & $\begin{array}{c}0.026 * * \\
(0.011)\end{array}$ & $\begin{array}{c}0.030 * * \\
(0.015)\end{array}$ \\
\hline State-level Enforcement & $\begin{array}{c}0.033 * * * \\
(0.010)\end{array}$ & $\begin{array}{c}0.017 * * \\
(0.007)\end{array}$ & $\begin{array}{c}0.018 * * * \\
(0.006)\end{array}$ & $\begin{array}{c}0.017 \\
(0.011)\end{array}$ \\
\hline Dependent Variable mean & \multicolumn{4}{|c|}{0.32} \\
\hline $\begin{array}{l}\text { Observations } \\
\text { R-squared } \\
\text { CONSPUMA FE } \\
\text { Year FE } \\
\text { CONSPUMA-specific Time Trend }\end{array}$ & $\begin{array}{c}150,141 \\
0.187\end{array}$ & $\begin{array}{l}150,141 \\
0.209 \\
\text { Yes } \\
\text { Yes }\end{array}$ & $\begin{array}{c}150,141 \\
0.209 \\
\text { Yes } \\
\text { Yes }\end{array}$ & $\begin{array}{l}150,141 \\
0.214 \\
\text { Yes } \\
\text { Yes } \\
\text { Yes }\end{array}$ \\
\hline
\end{tabular}

Notes: Table 11 reports the results from estimating equation (3) using households with at least one U.S. born child between 0 and 18 years of age with a likely undocumented parent. Hispanic ethnicity and lack of citizenship are as used as proxy for likely undocumented status. Panel A replaces the immigration enforcement index for two indexes that distinguish between police-based and employment-based enforcement. Panel B replaces the immigration enforcement index for two indexes that distinguish between local and state-level enforcement Specification 1 includes only family characteristics. Specification 2 includes area and time fixed effects. Specification 3 adds aggregate State/CONSPUMA controls, and Specification 4 further adds the CONSPUMAspecific time trend. Robust standard errors are shown in parentheses. Standards errors are clustered at the CONSPUMA level. $* * * \mathrm{p}<0.01, * * \mathrm{p}<0.05, * \mathrm{p}<0.1$. 
Table 12: Immigration Enforcement and the Probability of Living below the Poverty Line Transmission Mechanisms

\begin{tabular}{lcccc}
\hline & $\mathbf{1}$ & $\mathbf{2}$ & $\mathbf{3}$ & $\mathbf{4}$ \\
\hline Police-based Enforcement & $0.250 * * *$ & $0.244 * * *$ & $0.245^{* * *}$ & $0.244 * * *$ \\
& $(0.006)$ & $(0.005)$ & $(0.005)$ & $(0.005)$ \\
Observations & & & & 130,696 \\
R-squared & 130,819 & 130,819 & 130,696 & 0.217 \\
Dependent Variable Mean & 0.188 & 0.211 & 0.212 & \\
CONSPUMA FE & & & 0.31 & \\
Year FE & & Yes & Yes & Yes \\
CONSPUMA-specific Time Trend & & Yes & Yes & Yes \\
\end{tabular}

Notes: Table 13 reports the results from estimating equation (3) using 'intact' households -namely, households with a married head whose spouse is present- with at least one U.S. born child between 0 and 18 years of age with a likely undocumented parent. Hispanic ethnicity and lack of citizenship are as used as proxy for likely undocumented status. Specification 1 includes only family characteristics. Specification 2 includes area and time fixed effects. Specification 3 adds aggregate State/CONSPUMA controls, and Specification 4 further adds the CONSPUMA-specific time trend. Robust standard errors are shown in parentheses. Standards errors are clustered at the CONSPUMA level. $* * * \mathrm{p}<0.01, * * \mathrm{p}<0.05, * \mathrm{p}<0.1$. 
Figure 1: Geographic Variation in Enforcement over Time

Panel A: Year 2004
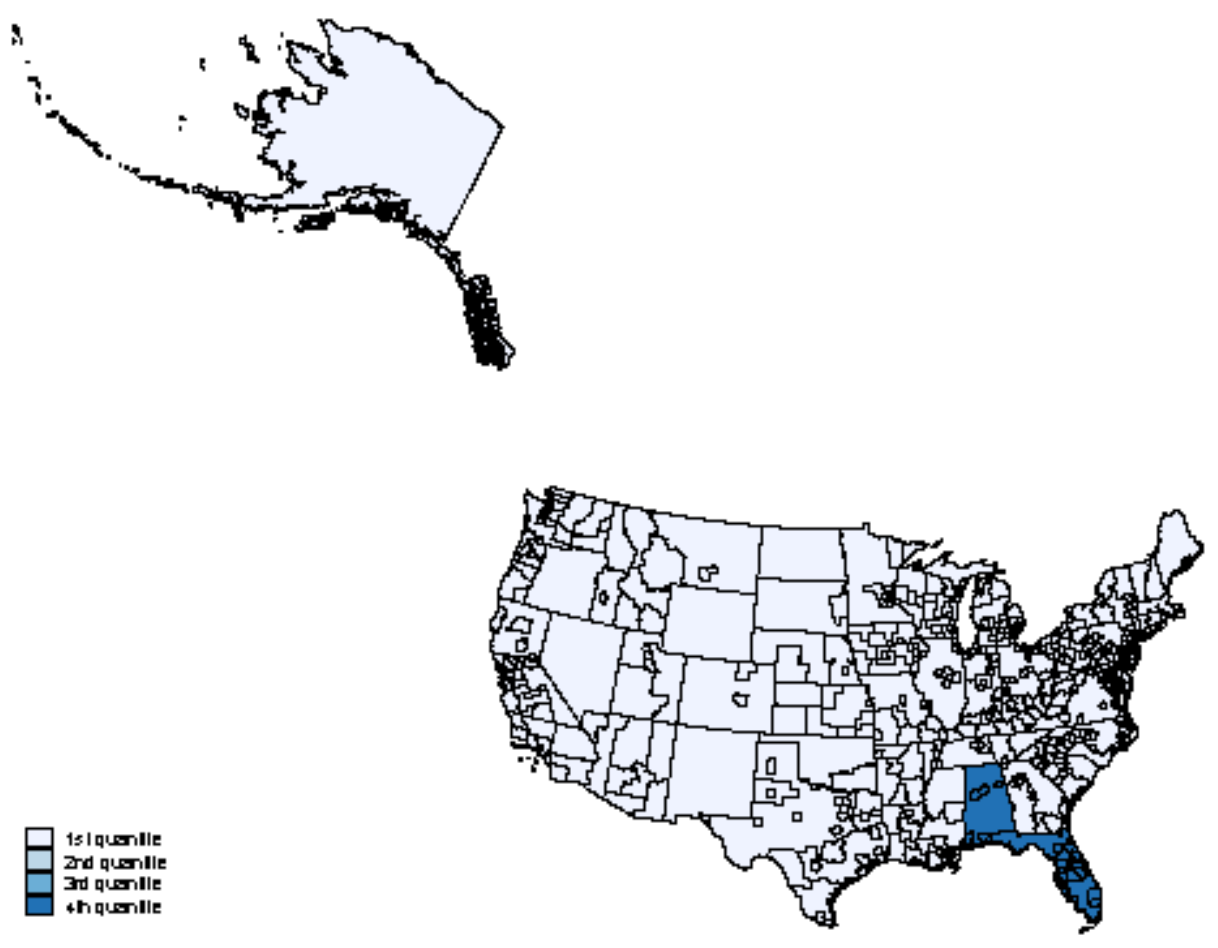

Panel B: Year 2007
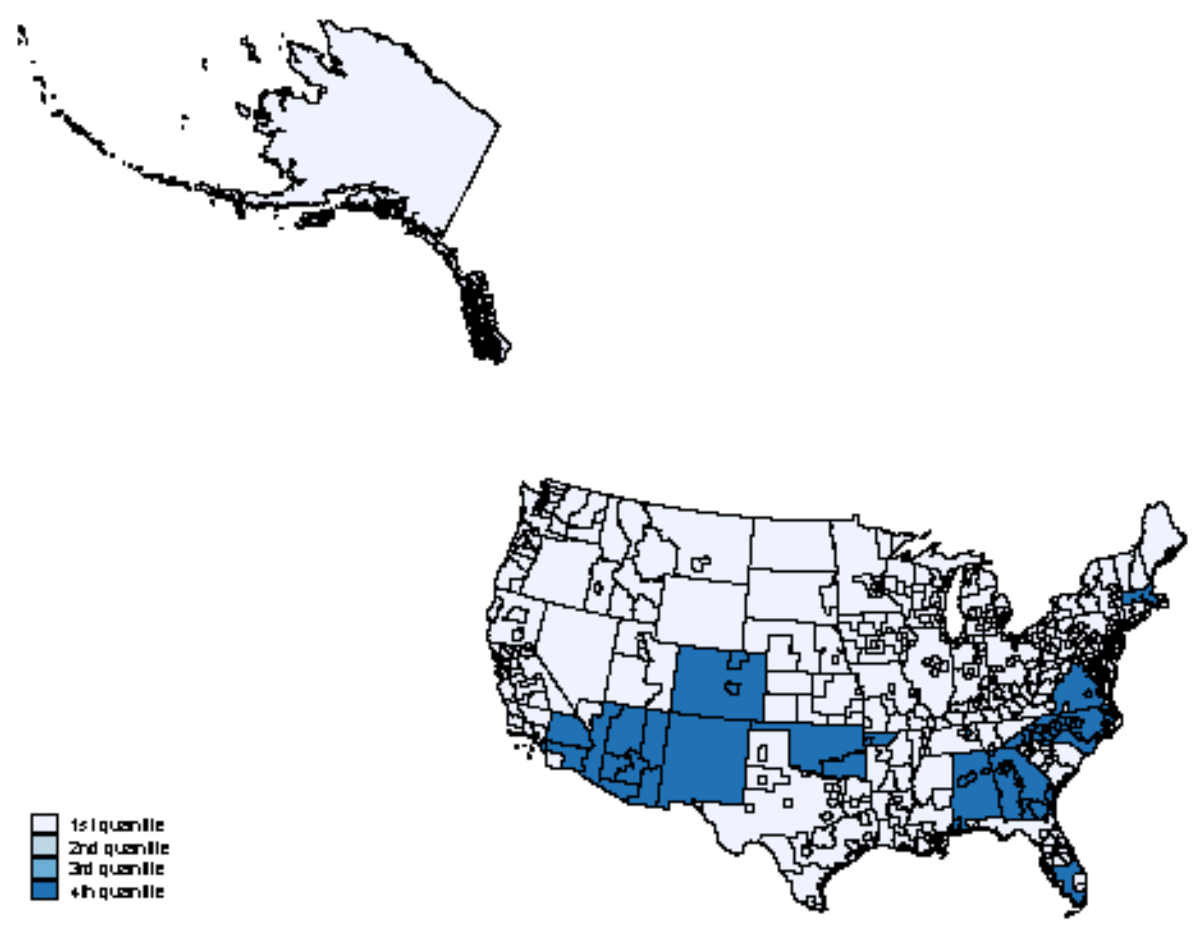
Panel C: Year 2010

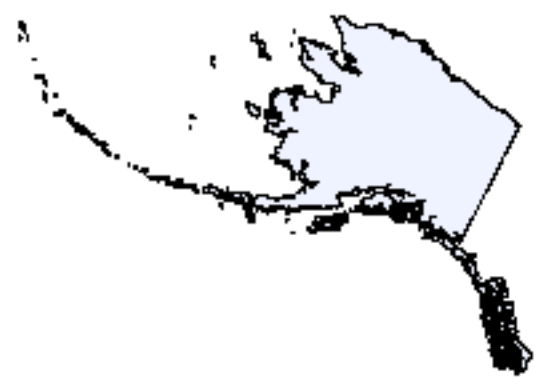

zod quenlle

thiserille

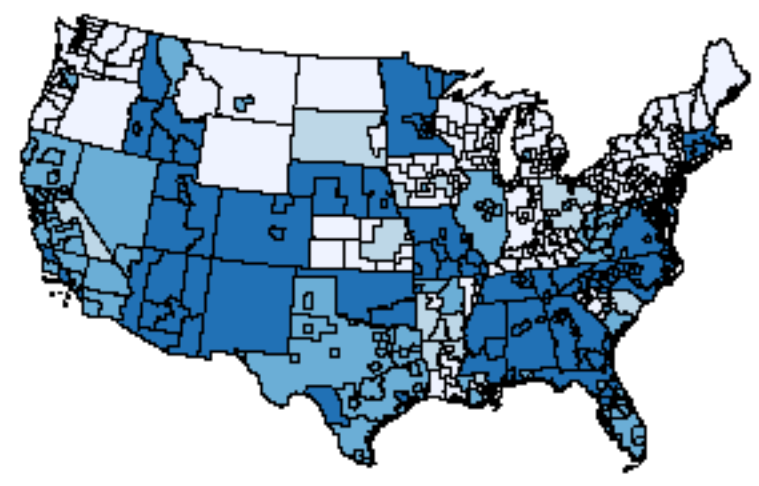

Notes: Figure 1 shows the roll out of immigration enforcement measures between 2004 and 2010. The years correspond to the sample period covered by the household income and poverty measures in the 2005-2011 ACS surveys, which always refer to one year prior. Lighter colors correspond to lower levels of enforcement (captured by the interior immigration enforcement index $E I_{c, t}$ ) in CONSPUMA $c$ in yea 
Appendix A

Table A.1: Description of Enforcement Laws

\begin{tabular}{|c|c|c|c|c|c|c|c|c|}
\hline $\begin{array}{l}\text { Nature of the } \\
\text { Law }\end{array}$ & Law & Years & $\begin{array}{l}\text { Area of } \\
\text { application }\end{array}$ & Objective & $\begin{array}{l}\text { Who is } \\
\text { applying it? }\end{array}$ & $\begin{array}{l}\text { Geographic } \\
\text { Coverage }\end{array}$ & Signed by & Types \\
\hline \multirow[t]{3}{*}{$\begin{array}{l}\text { Police-Based } \\
\text { Measures }\end{array}$} & $287(g)$ & $\begin{array}{l}2002- \\
2012\end{array}$ & Street/Jail & $\begin{array}{l}\text { Make } \\
\text { communities } \\
\text { safer by the } \\
\text { identification } \\
\text { and removal } \\
\text { of serious } \\
\text { criminals }\end{array}$ & $\begin{array}{l}\text { State and } \\
\text { local law } \\
\text { enforcement } \\
\text { entities }\end{array}$ & $\begin{array}{l}\text { State and } \\
\text { Local }\end{array}$ & $\begin{array}{l}\text { State and local } \\
\text { enforcement } \\
\text { entities signed } \\
\text { a contract } \\
\text { (Memorandum } \\
\text { of Agreement } \\
\text {-MOA) with } \\
\text { the U.S. } \\
\text { Immigration } \\
\text { and Customs } \\
\text { Enforcement } \\
\text { (ICE) }\end{array}$ & $\begin{array}{l}\text { Task Force: allows local } \\
\text { and state officers interrogate } \\
\text { and arrest noncitizens during } \\
\text { their regular duties on law } \\
\text { enforcement operations. } \\
\text { Jail enforcement permits } \\
\text { local officers to question } \\
\text { immigrant who have been } \\
\text { arrested on state and local } \\
\text { charges about their } \\
\text { immigration status. } \\
\text { Hybrid model: which allow } \\
\text { participate in both types of } \\
\text { programs. }\end{array}$ \\
\hline & SC & $\begin{array}{l}2009- \\
2014\end{array}$ & $\begin{array}{l}\text { Nation's } \\
\text { jail and } \\
\text { prisons }\end{array}$ & $\begin{array}{l}\text { Identify } \\
\text { noncitizens } \\
\text { who have } \\
\text { committed } \\
\text { serious crime } \\
\text { using } \\
\text { biometric } \\
\text { information }\end{array}$ & Police & Local & Jurisdictions & \\
\hline & $\begin{array}{l}\text { OIL- } \\
\text { SB1070 }\end{array}$ & 2010 & Street/Jail & $\begin{array}{l}\text { Identification } \\
\text { noncitizen }\end{array}$ & $\begin{array}{l}\text { State and } \\
\text { local law } \\
\text { enforcement } \\
\text { entities }\end{array}$ & State & State governor & \\
\hline $\begin{array}{l}\text { Employment- } \\
\text { Based } \\
\text { Measures }\end{array}$ & $\begin{array}{l}\text { E- } \\
\text { Verify }\end{array}$ & 2006- & Firms & $\begin{array}{l}\text { Deter the } \\
\text { hiring of } \\
\text { unauthorized } \\
\text { immigrants. }\end{array}$ & Employer & State & State governor & \\
\hline
\end{tabular}

Note: Sources: National Conference of State Legislatures (NCSL) and U.S. Immigration and Customs Enforcement (ICE) 


\section{Appendix B}

Table B.1: Definition of Key Variables

Poverty 100

Poverty 150

Log (Real Household Income)

Single Headed Household

HH Head w/HS +

HH Head Does not Speak English

Years in the U.S. of the HH Head

Age of the HH Head

No. of Kids in the $\mathrm{HH}$

Unemployment Rate in CONSPUMA

Share Voting Republican in State
Dummy variable

1-Household income is below the poverty threshold

0-Otherwise

Poverty threshold: Established by the Social Security Administration in 1964, and subsequently modified by Federal interagency committees in 1969 and 1980.

Dummy variable

1-Household income is less than 1.5 times the poverty threshold

0-Otherwise

Household income is the total pre-tax money income earned by all members in the family from all sources for the previous year.

Dummy variable

1-Single headed family

0-Two-parent family

Educational attainment of the head of the family 1-Head of the household with more than HS diploma 0-Otherwise

English proficiency of the household head 1-Household head does not speak English or does not speak it well

0-Otherwise

Number of years of U.S. residency of the household head

Age of household head

Number of children ages 0 to 18 residing in the household

Unemployment rate by CONSPUMA and year

Share of votes going to Republican candidates for the U.S. House of Representatives by state and year. Source: Office of the Clerk, US House of Representatives, http://clerk.

house.gov/member_info/electionInfo/index.aspx. Values between election dates are calculated by linear interpolation.

Note: All the variables are constructed using 2005-2011 ACS data. 


\section{Appendix C}

Table C.1: Immigration Enforcement and the Probability of Living below the Poverty Line Identification Test for the Endogeneity of Immigration Enforcement \#2

\begin{tabular}{|c|c|c|c|c|}
\hline & 1 & 2 & 3 & 4 \\
\hline Share of HHs Living below the Poverty Line & $\begin{array}{c}0.011 \\
(0.078)\end{array}$ & $\begin{array}{l}-0.016 \\
(0.078)\end{array}$ & $\begin{array}{c}0.057 \\
(0.059)\end{array}$ & $\begin{array}{l}-0.012 \\
(0.078)\end{array}$ \\
\hline Share of Single Headed HHs & & $\begin{array}{l}-0.100 \\
(0.073)\end{array}$ & $\begin{array}{c}-0.014 \\
(0.033)\end{array}$ & $\begin{array}{c}-0.087 \\
(0.071)\end{array}$ \\
\hline Share of HH Heads with a HS Education or More & & $\begin{array}{l}-0.020 \\
(0.073)\end{array}$ & $\begin{array}{l}-0.021 \\
(0.067)\end{array}$ & $\begin{array}{l}-0.011 \\
(0.076)\end{array}$ \\
\hline Share of HH Heads without a HS Diploma & & $\begin{array}{c}0.052 \\
(0.067)\end{array}$ & $\begin{array}{c}0.047 \\
(0.047)\end{array}$ & $\begin{array}{c}0.024 \\
(0.062)\end{array}$ \\
\hline Share of non-English proficient $\mathrm{HH}$ heads & & $\begin{array}{c}0.065 \\
(0.084)\end{array}$ & $\begin{array}{c}0.096 \\
(0.111)\end{array}$ & $\begin{array}{c}0.046 \\
(0.080)\end{array}$ \\
\hline Average Number of Years in the U.S. & & $\begin{array}{c}0.000 \\
(0.004)\end{array}$ & $\begin{array}{c}-0.002 \\
(0.004)\end{array}$ & $\begin{array}{l}-0.001 \\
(0.004)\end{array}$ \\
\hline Share of Working HH Heads & & $\begin{array}{l}0.121 * \\
(0.064)\end{array}$ & $\begin{array}{c}0.136 * * \\
(0.065)\end{array}$ & $\begin{array}{c}0.084 \\
(0.068)\end{array}$ \\
\hline Average Age of HH Head & & $\begin{array}{l}-0.010 \\
(0.007)\end{array}$ & $\begin{array}{c}0.001 \\
(0.002)\end{array}$ & $\begin{array}{c}-0.008 \\
(0.007)\end{array}$ \\
\hline Average number of kids per $\mathrm{HH}$ & & $\begin{array}{c}-0.064 * * \\
(0.026)\end{array}$ & $\begin{array}{c}-0.065^{* *} \\
(0.028)\end{array}$ & $\begin{array}{c}-0.062 * * \\
(0.026)\end{array}$ \\
\hline Average Unemployment Rate in CONSPUMA & & & & $\begin{array}{c}-1.697 * * \\
(0.670)\end{array}$ \\
\hline Share Voting Republican in State & & & & $\begin{array}{c}0.049 \\
(0.242)\end{array}$ \\
\hline Constant & $\begin{array}{c}0.406 * * * \\
(0.033)\end{array}$ & $\begin{array}{c}0.784 * * * \\
(0.281)\end{array}$ & $\begin{array}{c}0.392 * * * \\
(0.117)\end{array}$ & $\begin{array}{c}0.671 \\
(0.636)\end{array}$ \\
\hline MSA FE & No & No & Yes & Yes \\
\hline Observations & 478 & 478 & 478 & 478 \\
\hline R-squared & 0.000 & 0.041 & 0.602 & 0.059 \\
\hline
\end{tabular}

Notes: Table C. 1 displays the results from estimating the following equation: $E I_{c}=\alpha+X_{c}^{\prime 2000} \alpha+Z_{c}^{\prime 2000} \mu+$ $\lambda W_{c}^{2000}+\varepsilon_{c}$, where $E I_{c}$ is the enforcement level when the enforcement index turned positive in CONSPUMA $c$. Sample: All CONSPUMAs. Robust standard errors are in parentheses and clustered at the Metropolitan Statistical Area (MSA) level. ***p<0.01, **p<0.05, ${ }^{*} \mathrm{p}<0.1$. 
Table C.2: Immigration Enforcement and the Probability of Living below the Poverty Line Identification Check for Endogenous Residential Location of Migrants \#2

(Sample: "Non-movers")

\begin{tabular}{lcccc}
\hline & $(\mathbf{1})$ & $\mathbf{( 2 )}$ & $\mathbf{( 3 )}$ & $\mathbf{( 4 )}$ \\
\hline & $0.044^{* * *}$ & $0.022^{* * *}$ & $0.023^{* * *}$ & $0.027^{* *}$ \\
Enforcement Index & $(0.009)$ & $(0.006)$ & $(0.005)$ & $(0.011)$ \\
& & & & \\
& Yes & Yes & Yes & Yes \\
Individual Characteristics & No & Yes & Yes & Yes \\
Years FE & No & Yes & Yes & Yes \\
CONSPUMA FE & No & No & Yes & Yes \\
State/CONSPUMA controls & No & No & No & Yes \\
CONSPUMA-trends & 121,669 & 121,669 & 121,669 & 121,669 \\
Observations & 0.180 & 0.203 & 0.203 & 0.209 \\
R-squared & & & 0.32 & \\
Mean Dependent variable & & & & \\
\hline
\end{tabular}

Notes: Table D1 reports the results from estimating equation (3) using a subsample of households with at least one U.S. born child between 0 and 18 years of age with an undocumented parent who did not move within the last year. Specification 1 includes only family characteristics. Specification 2 includes area and time fixed effects. Specification 3 adds aggregate State/CONSPUMA controls, and Specification 4 further adds the CONSPUMA-specific time trend. Robust standard errors are shown in parentheses. Standards errors are clustered at the CONSPUMA level. $* * * \mathrm{p}<0.01, * * \mathrm{p}<0.05, * \mathrm{p}<0.1$. 